\title{
Networks of Trade
}

For more than a millennium before the Columbian voyages, the Ohio Fiver Valley served as one of the great conduits of human civilization in North America. Each of the main prehistoric culture complexes of the central continent was communicated through the Ohio Valley along the region's network of waterways: the Hopewell, Adena, and Mississippian cultures each left its mark in the valley and contributed to a rich and complicated prehistoric legacy. The Ohio Valley emerged then, and has persisted ever since, as a distinctive cultural and economic zone. Influences and contacts flow through the region like blood through the back of a hand; its tributary rivers, united by the great artery of the Ohio River, have always tended to make travel, communication, trade - and conflict - defining features of Ohio Valley communities.

To begin with, there is the landscape. The Ohio River falls from its origins in the Allegheny foothills to the south and west for nearly a thousand miles, fed along the way by nine major rivers and dozens of smaller streams. On its southern bank, the Ohio Valley embraces both the hardscrabble hills of northern West Virginia and the fertile plains of the Kentucky bluegrass, a region marked off by the Alleghenies on the east and the Tennessee River to the south. On the north side of the Ohio the valley is especially accessible through an intricately branching pattern of subsidiary rivers. The big river ties the entire region together at the same time that it divides it in two.

If the Ohio Valley has a kind of internal coherence and unity, the watercourses that surround and feed into the valley have always helped connect it to the rest of the continent. The Mississippi River is the val- 
ley's most important conduit to the outside world; it connects with the Southeast, the Gulf coast, and even the peoples of Mexico and the Yucatan. To the west, the Missouri River serves as a means of communication with much of the Great Plains as far as the Rocky Mountains; on the north, the Great Lakes act as a natural point of intersection between residents of the Ohio Valley and their northern neighbors. Less directly, the Allegheny and Tennessee Rivers provide routes of contact to the eastern woodlands as well. Along all of these routes, indigenous peoples traveled and interacted from at least 400 B.C. until Europeans arrived on the scene. They left a complicated archaeological legacy that scholars have labored for years to disentangle in order to make sense of the region's prehistoric past.

The Ohio Valley was never home to great, centralized empires. In contrast to other regions of the Americas - central Mexico, the Andean highlands, and parts of southeastern North America, for example - the Ohio Valley was too porous and easily penetrated to withstand external influences. ${ }^{1}$ Instead the region was inhabited for at least a thousand years by relatively small, independent clusters of communities that periodically entered coordinated phases of economic, social, and cultural development.

During the Hopewell period (ca. 300 B.C.-A.D. 300), broadly shared culture patterns emerged throughout the Ohio Valley. They are revealed in distinctive mound burial sites, earthworks, and artifact styles, and taken together they suggest widespread contact and influence throughout the region. The mound site at Chillicothe, Ohio, has long been regarded as the prototype, and perhaps the point of origination, for Hopewell influence. But significant local variations remained; the Hopewell culture complex offers evidence, not of the formation of a unified empire of military or adminstrative domination, but instead of a period of cultural interaction and borrowing shared by a wide variety of communities, each developing according to its own dynamic. Similarly with the Adena complex, which emerged at roughly the same time in the central Ohio Valley. It is identified by a distinctive mortuary style, and Adena communities also probably shared a ceremonial complex in common, but they were not united under the kind of coercive imperial system that would have placed them under the rule of a single elite class or imposed regular tributes or common structures of community organiza-

1 Considerable work has been done in recent years on the late prehistoric and early historic native populations of the southeast; for an introduction to this literature, see Peter Wood, Gregory Waselkov, and M. Thomas Hatley, eds., Powhatan's Mantle: Indians in the Colonial Southeast (Lincoln, NE, 1989). 
tion upon them. ${ }^{2}$ If we allow the term "empire" to apply only to a dominant, coercive administrative-military complex, these culture systems do not qualify. If, on the other hand, we define empire more flexibly to include broadly shared economic, social, and cultural patterns - an empire, in other words, defined not by the dominance of a ruling elite but by patterns of activity and meaning that were common to the region at large - then the culture systems of the Ohio Valley could also be described as empires. They were, in fact, very much like the systems I have termed empires of commerce, which will be considered at greater length below.

The last great cultural efflorescence of the pre-Columbian period conforms to this same pattern. The Mississippian culture complex (ca. $800-1500$ A.D.) was widely dispersed, long-lived, and deeply influential in the period just before European contact. Its sites ranged throughout the Southeast, the Gulf Coast, and the Mississippi and Ohio Valleys; though their extraordinary scope and variety make them particularly difficult to describe comprehensively, some characteristics were common to them all. Mississippian communities were located in the "meander-belt zones" and alluvial floodplains of major rivers in eastern North America, which placed them in ecosystems that could support substantial populations. Mississippian peoples pioneered the corn-beans-squash agricultural complex that would become so important to Native Americans throughout the midcontinent and eastern woodlands, and the richly silted alluvial lands they settled were especially well-suited to that pattern. The oxbow lakes and marshy backwaters of the meander-belt zones also made fish and wildfowl easily available. ${ }^{3}$ Alongside this settlement pattern, distinctive Mississippian cultural forms arose and spread across a wide area. They are identified by telltale artifacts, especially a certain type of earthen mound, usually rectangular and truncated, and distinctive shell-tempered pottery. As Mississippian communities grew more complex, differences in status and power became more pronounced: the spatial organization of Mississippian towns and the rich artifacts found in some burial sites both indicate that clearly ranked social hierarchies were common to Mississippian communities. ${ }^{4}$

2 For an introduction to the Hopewell and Adena, see James E. Fitting, "Regional Cultural Development, 300 B.C. to A.D. I000," in William C. Sturtevant, gen. ed., Handbook of North American Indians, vol. XV: Northeast, ed. Bruce G. Trigger (Washington, DC, I978), pp. 44-57.

3 Bruce D. Smith, "Variation in Mississippian Settlement Patterns," in Smith, ed., Mississippian Settlement Patterns (New York, 1978), pp. 479-503.

4 On the origins of Mississippian culture generally see especially Bruce D. Smith, ed., The Mississippian Emergence (Washington, DC, 1990). 
But although Mississippian culture supported the rise of local elites, they never functioned as agents of a centralized administrative empire. Instead the Mississippian system was a network of interlinked regions bound together by patterns of material and cultural exchange. Whether the connections among Mississippian communities were forged by conquest, by trade, or by some combination of the two, the archaeological record of Mississippian culture varies significantly from site to site. ${ }^{5}$ Within each region, various kinds of societies and communities received and absorbed Mississippian influences in a variety of ways. The backbone of Mississippian culture was the Mississippi River, and its core was in the lower Mississippi Valley. As one of the great feeders of the Mississippi River, the Ohio was ideally situated to receive and disseminate the influences of the Mississippian cultural core. And as with the region's earlier culture complexes, Mississippian traits filtered into the region and spread throughout its settlements. One of the most important centers of Mississippian influence anywhere on the continent (and the greatest single prehistoric site north of Mexico) was at Cahokia, Illinois. There, within an area of nearly six square miles, a complex of more than a hundred man-made mounds - the largest covering almost sixteen acres - was constructed during the early period of Mississippian development.

From about A.D. 800-900 until at least 1250 , Cahokia was one of the great centers of public and ceremonial life in the western hemisphere. By A.D. I 200, Cahokia served a community with a population of perhaps 30,000. In its immediate hinterland, a dozen or more satellite communi-

${ }^{5}$ For a thoughtful analysis of site variations and the evolution of archaeological interpretations of the Mississippian era see Jon Muller, Archaeology of the Lower Ohio River Valley (Orlando, FL, 1986), pp. I69-272. It has been argued that the Mississippians were a distinct people who came as conquerors and displaced preexisting populations. Certainly there is something to this view - the spread of Mississippian culture, and perhaps a distinctive Mississippian population, could not have proceeded without conflict where it was displacing older ways and, in some places at least, other peoples - but even if the spread of Mississippian culture is interpreted as a manifestation of conquest it is important to recognize the limits of that conquest. Unlike the more familiar empires of conquest - the Aztec empire in central Mexico, or the Roman empire of an earlier period - the Mississippians apparently did not create centralized systems of administration or tribute collection, nor did they establish a central ruling class. For discussions of the Mississippians that emphasize conquest, see Francis Jennings, The Founders of America: How Indians Discovered the Land, Pioneered in It, and Created Great Classical Civilizations; How They Were Plunged into a Dark Age by Invasion and Conquest; and How They Are Reviving (New York, 1993), and in an account that focuses on the coastal region of the Carolinas, James Merrell, The Indians' New World: Catawbas and their Neighbors from European Contact Through The Era of Removal (Chapel Hill, I989), pp. I3-I 8 . 
ties grew up alongside it. ${ }^{6}$ These were not insular, inward-looking settlements; on the contrary, given the enormous range and influence of Mississippian culture, it may be most useful to think of Cahokia as a "gateway center," a cultural focus from which rays of influence diverged across the countryside, touching many thousands of people living beyond the American Bottom. Artifacts from widely scattered sources throughout North America have turned up at Cahokia, suggesting that traders were traveling an astonishingly expansive circuit by the height of the Mississippian period. To Cahokia they carried superbly crafted artifacts and raw materials from Mexico, the Great Lakes, the Atlantic coast, and the central Great Plains. ${ }^{7}$ In the final phase of the Mississippian period (ca. A.D. 1250-1500), Mississippian influences were everywhere in the Ohio Valley: at the Fort Ancient sites, clustered around the mouths of the Miami and Scioto Rivers; throughout the central Illinois River Valley; at the Kincaid sites, near the confluence of the Cumberland, Tennessee, and Ohio Rivers; and at the Angel and Caborn-Welborn sites near the mouth of the Wabash. ${ }^{8}$

At the moment of Columbus' first landfall in the Americas, the greater Ohio Valley thus seems to have been home to a sizable, interconnected indigenous population governed by well-developed systems of authority and meaning. There is evidence for ruling elites at most of its sites; for complex religious and ceremonial patterns; highly developed craft skills; and an extensive hinterland of interdependent communities linked by networks of exchange. ${ }^{9}$

What accounts for the collapse of Mississippian culture in central North America? To some extent, its rapid fall remains a mystery. Since the nineteenth century, archaeologists have entertained many possibilities: external invasion; a series of crop failures; a successful revolt against a ruling caste. Recent advances in our understanding of the epidemiology of European contact in the Americas suggest another possibility: the decline may have been caused, or at least hastened, by the ef-

${ }^{6}$ Melvin L. Fowler, "Cahokia and the American Bottom: Settlement Archaeology," in . Smith, ed., Mississippian Settlement Patterns.

7 John E. Kelly, "Cahokia and Its Role as a Gateway Center in Interregional Exchange," in Thomas Emerson and R. Barry Lewis, eds., Cahokia and the Hinterlands: Middle Mississippian Cultures of the Midwest (Urbana, IL, I99I), pp. 6I-80; for a general discussion of long-range patterns of exchange, see William A. Turnbaugh, "Wide-Area Connections in Native North America," American Indian Culture and Research Journal, I (1976), 22-28.

${ }^{8}$ Smith, ed., Mississippian Settlement Patterns, throughout.

9 The complicated interrelations between core settlements like Cahokia and hinterland communities cannot be characterized simply; for a general view, see the excellent collection of essays in Emerson and Lewis, eds., Cahokia and the Hinterlands. 
fects of the first Spanish landfalls in Mesoamerica. If trading networks and travel routes connected the population of the Ohio Valley with Mexico and the Gulf coast, it is entirely possible that, from about $\mathbf{5} 500$ on, devastating waves of epidemic disease could have swept through the continent along the great waterways that connected its population centers. ${ }^{10}$ If smallpox, typhus, measles, and other European pathogens thus found their way to the Ohio Valley periodically, rapid depopulation would have been the result. We now have reliable information about the effects of European disease on Indian populations who were continuously exposed to them. During the first generation of exposure, they generally declined by something approaching $50 \%$; after a century of sustained contact, population decline would have been on the order of $90 \% .{ }^{11}$ With intermittent rather than sustained exposure, the demographic catastrophe of the sixteenth century in the Ohio Valley would not have been so severe; nevertheless, even isolated waves of epidemic disease would have carried away a significant proportion of the region's population.

The advance of alien pathogens along the principal travel and communication routes of the central continent would have converted the blessings of geography in the Ohio River Valley into a curse of unparalleled proportions. The network of rivers which had heretofore facilitated contact and cultural diffusion would suddenly have become, inexplicably, a transmitter of disease and death. One natural reaction for survivors would have been to flee to other communities; they, too, would then become agents of disaster, visiting mysterious ailments upon their neighbors. Eventually, experience would provide communities with a rationale for withdrawal and isolation. It is easy to imagine how parties of messengers or traders arriving from the south might have been shunned by the increasingly fearful and suspicious clusters of surviving villagers: under the pressure of rapid and substantial population decline,

${ }^{10}$ This possibility has been suggestively explored by Alfred Crosby, in Ecological Imperialism: The Biological Expansion of Europe, 900-1900 (New York, 1986), pp. 209-2I 5; I am also indebted for the following discussion to Ralph J. Coffman, "PreColumbian Trade Networks in the Missouri, Ohio and Mississippi River Valleys and Their Importance for Post-Columbian Contact," paper presented at the Missouri Valley History Conference, Omaha, NE, March 1992. For an alternative interpretation of Mississippian decline in the Cahokia hinterlands, which places less emphasis on European diseases and argues for a period of "chronic, deadly warfare" in the 15th century, see Neal Salisbury, "The Indians' Old World: Native Americans and the Coming of Europeans," The William and Mary Quarterly, 3rd Ser., 53 (I996), 435-458.

11 Two recent works carefully summarize and assess the work of a generation of historical demographers of Native America; see William Denevan, ed., The Native Population of the Americas in 1492, 2nd ed. (Madison, WI, 1992), and Russell Thornton, American Indian Holocaust and Survival: A Population History Since 1492 (Norman, OK, 1987). 
people are likely to have turned in on themselves and allowed the commercial, ceremonial, and tribute ties that had bound them into a larger culture system to lapse in the interest of survival. Like islands exposed by the receding tide of Mississippian influence, the surviving fragments of population may have passed the last half of the I 6 th century and the first part of the 17 th regrouping along kin- and clan-based lines, beginning again to construct a social world for themselves out of the rudimentary building blocks of civilization.

In the I650s, French missionaries and traders began to extend their contacts beyond the Great Lakes for the first time. When they asked about the people of the western Ohio Valley, native informants described them as a formidable and unified power. One report indicated that Frenchmen would encounter a great confederacy of Illinois Indians which embraced sixty villages and towns and was capable of putting twenty thousand warriors into the field. ${ }^{12}$ As Frenchmen gained firsthand knowledge of these peoples, however, they discovered that the western Ohio Valley was occupied, not by a single, politically unified population, but instead by numerous confederacies, tribes, and bands of Indians, each of which sought to deal with the French independently, on its own terms.

As Richard White has recently argued, the French were encountering, without fully realizing it, a shattered social world in the Ohio Valley. On top of the dissolution of Mississippian culture and the devastation by disease that may have accompanied it, the region was also beginning to feel the effects of sustained and brutal Iroquois attacks by the 1650 s and I 660 s. $^{13}$ These attacks were pushing some groups from the Great Lakes region westward, devastating or destroying others, and scrambling earlier definitions of territory and identity throughout the Great Lakes and the Ohio Valley. The arrival of French traders and missionaries gave to the Indians occupying the western half of the Ohio Valley - the Illinois country, as the French called it - a means to reconstruct a social universe with a meaningful focus. Perhaps Onontio, the symbolic father figure of the French alliance, was powerful and appealing to the native occupants of the Illinois country in part because he helped to revive echoes of an earlier, more fully developed culture system which had given shape and meaning to past generations in the region, and which survived into the middle of the 17 th century as a residual social memory. Perhaps. For whatever reason, French traders and missionaries were welcomed into

12 [Gabriel Dreuillettes], "Relation of $1657-1658$," in Reuben G. Thwaites, ed., The Jesuit Relations and Allied Documents, 73 vols. (Cleveland, I896-1901) [hereafter JR], vol. XLIV, p. 247.

${ }^{13}$ Richard White, The Middle Ground: Indians, Empires, and Republics in the Great Lakes Region, I650-1815 (New York, I99I). 
the Ohio Valley during the second half of the 17 th century. With their arrival, the island communities of the interrelated but fragmented peoples who survived the fall of Mississippian culture could be bound together once again in a wider system of commerce, mediation, and cultural exchange.

\section{II}

When French traders and missionaries first ventured beyond the Great Lakes and into the Illinois country, they encountered a bewildering array of peoples. In part the problem was simply a profusion of names: dozens of tribal labels appear in the earliest documents, many of them only once or twice. In part, too, the confusion stemmed from the scrambled and apparently deteriorating lines of political authority in the region. Ostensibly these were tribal peoples, so that lines of authority should have run through channels of family, kin, and tribe, but individual villages often contained members of more than one tribe and the allegiances of their residents were sometimes far from clear. This was the fractured social world of post-Mississippian culture; now as in the $17^{\text {th }}$ century, it defies easy description or comprehension. ${ }^{14}$ Nevertheless, broader patterns of social organization still exerted some influence; the earliest French explorers encountered two weakly unified confederacies of tribes in the Illinois country - the Illinois confederacy and the Miami confederacy - and began to cultivate relations with each of them.

The Illinois and Miami Indians together dominated the territory bounded by the Mississippi River on the west, the Ohio River to the south, the Miami River to the east, and the lower tip of Lake Michigan to the north - essentially the western half of the Ohio Valley. Both participated in what anthropologists describe as the Central Algonquian culture complex. They were patrilineal and patriarchal societies. They relied for food primarily on agriculture, and particularly on corn, and they supplemented their crops with hunting, especially for deer and buffalo. ${ }^{15}$

Each of these two confederacies was composed of a number of dis-

14 By far the best comprehensive account of this region in the French period is in White, Middle Ground.

15 The anthropological literature on the Illinois and Miamis is uneven, and sources are unsatisfactory, precisely because they were experiencing such upheaval during the era of early contact; see White, Middle Ground, pp. 16-17 and following. The most useful anthropological analysis is Charles Callender, Social Organization of the Central Algonkian Indians, Milwaukee Public Museum Publications in Anthropology no. 7 (Milwaukee, r962). 
tinct tribal units, though in each the number of member tribes was unclear at first and seemed to diminish gradually through the first several decades of contact. The earliest French travelers identified at least I 2 different groups as members of the Illinois "nation," but by the end of the I 7 th century the number had dropped to four: the Kaskaskias, the Peorias, the Cahokias, and the Tamaroas. Sometime around 1700 a fifth tribe, the Michigameas, moved into Illinois territory from the south and was incorporated into the confederation. Though they remained allies, these tribal groups grew steadily more independent of one another in the years after the arrival of the French. ${ }^{16}$

Similarly, early chroniclers named six different constituent groups as members in the Miami confederation, but by 1700 there were only four; the "disappeared" groups coalesced into the Miami tribe. The other three tribes of the confederacy were the Piankashaws, the Ouiatanons (known later in British sources as the Weas), and the Pepikokias, who were absorbed into the Ouiatanon tribe around $\mathbf{1 7 4 5}$. The members of the Miami confederacy, like those of the Illinois, remained allies throughout the colonial period, but the strength of this connection could be tenuous. Each tribe maintained a distinct territory and autonomous political leadership. ${ }^{17}$

These confederacies were less units of political organization than sources of social and cultural identity. When the first French explorers visited the Illinois confederacy, it maintained a central community on the upper Illinois River - known to the French as the "Great Village" of the Illinois - where all the constituent tribes gathered during the summer. The Great Village served as their principal agricultural, political, cultural, and ceremonial center; here the Illinois tribes affirmed their shared identity in lacrosse matches, social, political, and religious rituals, planting and harvesting, hunting, and feasting. In fall, the confederacy dispersed into small hunting bands that wintered in a series of camps scattered between the Illinois and Mississippi Rivers. The Miami confederacy lacked such a central settlement; although the Miami tribes recognized their common origin, there appears to have been little to bind them together in the postcontact period. ${ }^{18}$

The timing of Frenchmen's first contacts with the Illinois and Miami Indians was crucial in shaping the Indians' reaction to them. To begin

16 For an introduction to the anthropological and historical literature on the Illinois, see Charles Callender, "Illinois," in Trigger, ed., Handbook, p. 673.

17 Callender, "Miami," in Trigger, ed., Handbook, pp. 68 r-689.

18 Margaret Kimball-Brown, Cultural Transformations Among the Illinois: An Application of a Systems Model, Publications of the Museum, Michigan State University, vol. I no. 3 (East Lansing, 1979), pp. 227-229. 
with, the confederacies were disintegrating as effective units of political organization by the middle of the I 7 th century, leaving the Illinois and Miami Indians increasingly vulnerable in their relations with outsiders. The two confederacies had been united in a single, larger confederation until very shortly before French contact. ${ }^{19}$ Whether the dissolution of this larger Illinois-Miami confederacy was a late stage of Mississippian decline or the result of a localized dispute, it is symptomatic of a broader pattern: the region's Indian population was becoming steadily less unified. On its own terms such disunity should not be read as a failure of the political or social order; it may reflect a dynamic sense of independence among the constituent groups of the confederation. But in times of crisis there is strength in numbers. Whatever else it might indicate about the communities of the Illinois and Miami Indians, the dissolution of their joint confederacy could pose a severe threat to their ability to defend themselves against outside aggression.

The problem of defense became a matter of urgent concern beginning in the I650s, when the Illinois country was first visited by war parties from the Five Nations of the Iroquois. The Iroquois had reached a crisis point in their relations with neighboring European and Indian powers by the early I 640 os. They responded by embarking on a half-century of particularly destructive and wide-ranging warfare. The Iroquois sought to capture and monopolize the trade in beaver pelts throughout the Great Lakes and the Ohio Valley, to terrorize their enemies, and to carry captives back to Iroquoia to help offset their own rapid population decline. In these efforts they were astonishingly successful. They destroyed or displaced a succession of Indian tribes - the Wenros, the Hurons, the Petuns, the Neutrals, the Eries - claiming domination over conquered territories and either dispersing or absorbing their populations. By the I 65 os Iroquois warriors were making their way into the Illinois country, and they brought with them a terrifyingly destructive pattern of warfare to which the Illinois and Miami Indians were ill-equipped to respond. ${ }^{20}$

The Iroquois raids raised the stakes of war to a new level. The most familiar form of war in the Illinois country was a mourning war, a local-

19 Both oral tradition and anthropological research confirm the hypothesis of a single united confederacy in the immediate pre-contact period; for the former, see Thomas Forsyth, "An Account of the Manners and Customs of the Sauk and Fox Nations of Indians Tradition," in Emma H. Blair, ed., The Indian Tribes of the Upper Mississippi Valley and Region of the Great Lakes, 2 vols. (Cleveland, I9I I), vol. II, pp. I99-20I, and for the latter, Callender, Social Organization, p. I; Kimball-Brown, Cultural Transformations Among the Illinois, pp. 228, 233-235; Emily J. Blasingham, "The Depopulation of the Illinois Indians," Ethnobistory, 3 (1956), 361-362.

20 Daniel Richter, The Ordeal of the Longhouse: The Peoples of the Iroquois League in the Era of European Colonization (Chapel Hill, I992), especially pp. 50-74. 
ized, limited, and personal style of warfare that was intended to exact revenge for an earlier death. Mourning and revenge were often inseparable for the Illinois and Miami Indians, and the mourning war took on an almost ritualized form. With few exceptions, war was not intended to inflict mass destruction on an enemy people. Thus, even after the Illinois and Miami Indians began to receive French guns in trade sometime around the mid-I650s, they did not immediately conceive of them as efficient instruments of death. Instead, in keeping with their limited pattern of warfare, they used guns "to inspire, through their noise and smoke, terror in their Enemies." This was entirely fitting in the context of a mourning raid, but it would not serve them well in the face of a concerted Iroquois attack. ${ }^{21}$

The Illinois and Miami Indians soon discovered what such an attack could mean. During a raid on the Great Village of the Illinois in I 680, an Iroquois war party came upon the town at a time when most of its young men were away hunting. Following a prolonged series of skirmishes, the Iroquois raiders finally fell upon an unprotected group of seven hundred people, predominantly women and children, killing hundreds of them and taking many more as captives. ${ }^{22}$ Even for a strong and united people, the Iroquois threat would have presented a formidable challenge; the fragile, disordered world of the western Ohio Valley was especially vulnerable to its terrors.

The first Frenchmen to visit the Illinois country thus encountered a beleaguered people. Pressured by the Iroquois from the east - and, at the same time, by the Sioux from the west - the Illinois and Miami confederacies were weakened and disunified. When French missionaries and traders ventured into Illinois and Miami villages for the first time, they were received practically (even literally) as gods by Indian leaders who recognized in their arrival the possibility of deliverance. When Father Jacques Marquette and Louis Joliet made their famous trip down the Mississippi in 1673 , they visited an Illinois village where they were greeted enthusiastically by a party of elders. "Never has the earth been so beautiful," one of the Illinois men is supposed to have told them, "or the sun so Bright as today." 23 Nicholas Perrot, one of the first French traders to venture into the Illinois country, was reportedly told by a

${ }^{21}$ Kimball-Brown, Cultural Transformations, pp. 244-245; "Marquette's First Voyage," $J R$, vol. LIX, p. I 27.

22 "Cavelier de la Salle de I679 a I68I," in Pierre Margry, ed., Découvertes et Établissements des Français dans l'Ouest et dans le Sud de L'Amérique Septentrioniale (I614-1754): Mémoires et Documents Originaux, 6 vols. (Paris, I876-I886), vol. I, pp. 503-5I3.

23 “Marquette's First Voyage," JR, vol. LIX, p. I2I. 
Potawatomi chief, "You are one of the chief spirits because you use iron. It is for you to rule and protect all men. Praised be the sun, who has taught you and sent you to our country." A year later Perrot became the first Frenchman ever to visit a Miami village, and he promised its leaders,

You will become another nation when you know us. I am the dawn of that light, which is beginning to appear in your lands; which precedes the sun; which will shine brightly and will cause you to be born again, as if in another land, where you will more easily find all necessities in greater abundance. ${ }^{24}$

Though we might read these reports skeptically, the solar metaphors were more plausible under the circumstances in which they originated than they appear today. The French could, indeed, offer the Illinois and Miami Indians a center of gravity and a source of material aid and sustenance. Perrot's inflated prophecy was partially fulfilled in 1683 , when Réné-Robert, Cavelier de La Salle, and his lieutenant, Henri Tonti, erected the first French fort and trading post in the Illinois country. With the permission of the Illinois confederacy, they selected a site on a high, rock-faced bluff overlooking the Illinois River near the confederacy's Great Village, erected several cabins and storehouses, surrounded them with palisades, and named the result Fort St. Louis (Fig. I).

Again French timing was good, because in the early I680s the frequency and intensity of Iroquois attacks accelerated. In the previous year the Illinois Indians suffered what must have been one of the most devastating assaults of their entire history. Iroquois warriors reportedly returned from their 1682 raid with about 700 Illinois prisoners; they claimed that they "killed and ate" another 600 on the spot. With the fort serving as a center of defense, the population of the Great Village ballooned from perhaps I 2,000 to as many as 20,000 . This enlarged population included the Miami tribes, who chose to overlook their differences with the Illinois Indians in exchange for French protection, and about rooo Shawnees who had recently been driven out of their homeland between the Ohio and Tennessee Rivers by Iroquois attacks. ${ }^{25}$

${ }^{24}$ Charles Claude Le Roy, Bacqueville de la Potherie, "History of the Savage Peoples Who are Allies of New France," in Blair, ed., Indian Tribes, vol. I, pp. 309, 330. I have modernized the translations of these passages.

25 "Cavelier de La Salle de 1679 a 1681," Margry, ed., Découvertes et Établissements, vol. I, p. 469; Richter, Ordeal of the Longhouse, pp. I44-I 45. For the pre-fort population, Louis Hennepin wrote that the village contained 460 cabins, with four to five fires per cabin and one or two families per fire; see Description of Louisiana Newly Discovered to the Southwest of New France by Order of the King, Marian E. Cross, trans. (Minneapolis, 1938) [orig. pub. Paris, 1683], p. 65. For the population after the construction of the fort see Franquelin's map, which gives estimates of warrior populations for the villages surrounding the fort. It is reproduced in Fig. I. 


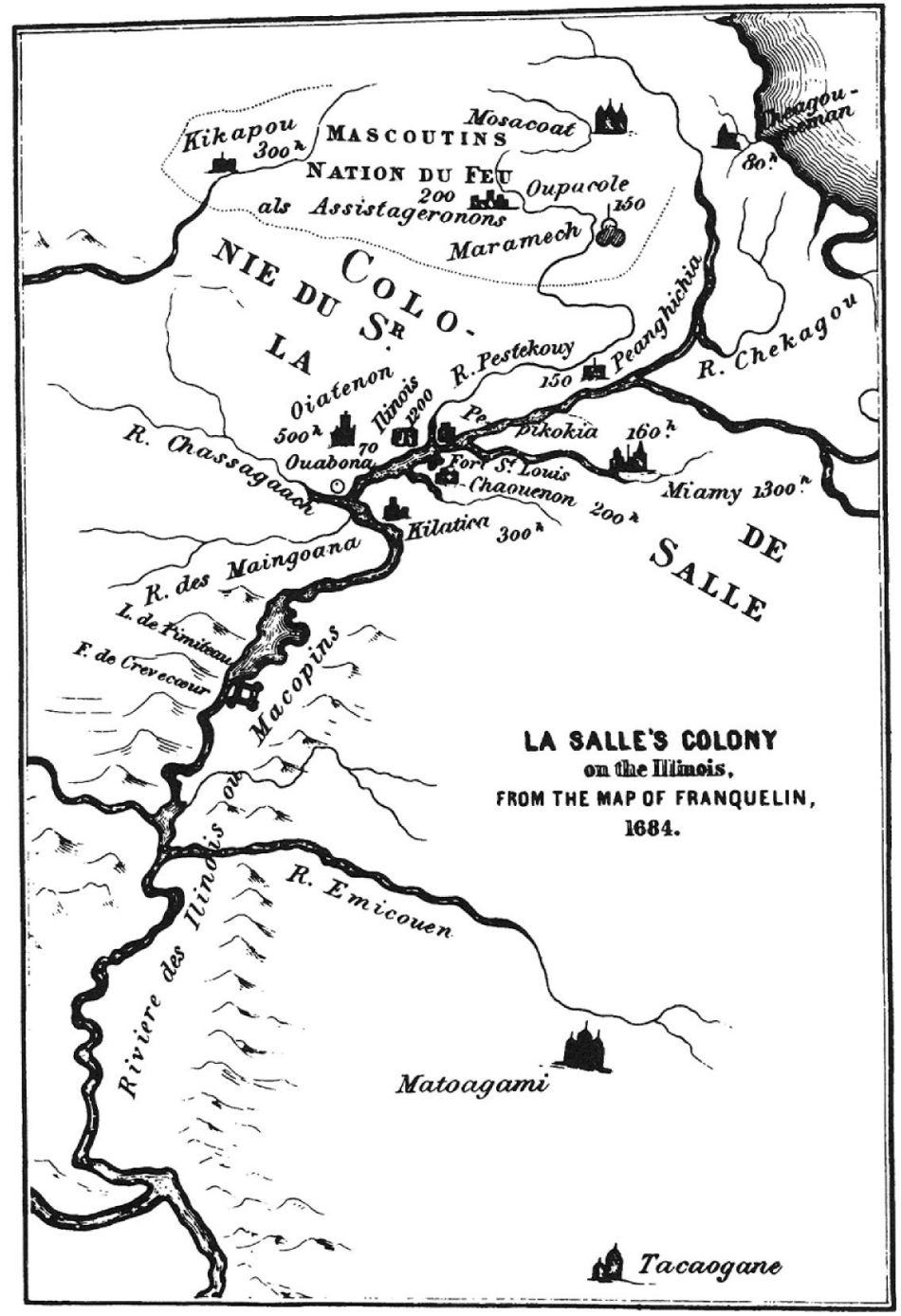

Figure I. Fort St. Louis and environs, I684, showing approximate location and estimated warrior population in nearby Indian villages. From an engraving published in Francis Parkman, La Salle and the Discovery of the Great West (London, I 869), based on a manuscript map by Jean Baptiste Louis Franquelin. 
When Iroquois war parties arrived in the Illinois country in the spring of 1683 , the local Indian population was well-fortified and wellarmed and the Iroquois were driven out. In the following year Iroquois warriors returned; encountering a party of French traders, they inquired warily whether La Salle and Tonti were at the fort, and how many men they might have with them. They decided to proceed with the attack, but once again they were driven off. Beginning in 1685 New France and its Indian allies took the offensive against the Iroquois, and the focus of hostilities shifted to the east. With the immediate threat of war relieved, the population around Fort St. Louis began to disperse. ${ }^{26}$

As the fort's military importance declined, its commercial value grew. By bringing French traders, known as coureurs de bois, directly into contact with Illinois Indians for the first time, it gave a tremendous boost to the power and status of the Illinois. Even before Fort St. Louis was built, the Illinois Indians had developed limited trading ties with the Green Bay post through Ottawa middlemen, with whom designated Illinois emissaries exchanged animal pelts and slaves for French merchandise. The slave trade probably grew out of the traditional practice of taking captives as replacements for fallen warriors in battle - a common variation on the mourning-war theme - but the enticement of European trade goods soon encouraged the Illinois warriors to increase their take of live captives and use them as a commodity. Their victims in the slave trade came principally from among the Illinois' traditional enemies west of the Mississippi, especially the Pawnees and the Sioux. By I670, Marquette could report that the Illinois "take a great many Slaves," for whom they received from the Ottawas "Muskets, Powder, Kettles, Hatchets and Knives."27

With the construction of Fort St. Louis, the Illinois Indians' involvement in trade grew and the confederacy's status in the eyes of its neighbors was transformed. From a people in decline, the Illinois once again became a considerable power in the region; after fearing for its territorial integrity and even its survival in the face of earlier Iroquois and Sioux attacks, the confederacy could again make war on and exact tribute from a host of nearby peoples. The scope of Illinois slave raids continued to expand, until they became a source of considerable concern and aggravation to French colonial officials. ${ }^{28}$ At the same time, the Illinois

26 "Tonti's Memoir [1693]," in Louise Kellogg, ed., Early Narratives of the Northwest, r634-1699 (New York, I9I7), pp. 305-306, 308-31 I; M. de Beauvais et al., "Relation d'un Voyage dans le pays des Ilinois ...," 28 Mai I684, Archives des Colonies, Série C ${ }^{11}$ A, vol. 6, pt. $x$, National Archives of Canada, Ottawa.

27 Marquette to Father Superior, I669-I670, JR, vol. LIV, p. I9I.

${ }^{28}$ See André Pénicaut, Fleur De Lys and Calumet: Being the Pénicaut Narrative of French 
also began to serve the same middleman role for other Indian tribes that the Ottawas had once served for them. Members of the Osage and Missouri tribes, for example, established a trading alliance with the Illinois Indians and made annual visits to their villages to trade for French goods, especially hatchets, knives, and awls. ${ }^{29}$ Such trading alliances were conducted according to a well-established protocol, in which representatives of the Illinois Indians consistently interposed themselves between traders from outlying tribes and the French coureurs de bois. This subsidiary trading pattern further profited the Illinois Indians, whether profits are calculated in prestige or in material rewards. Probably the former gain was more important; their middleman status solidified the dominant position of the Illinois Indians among their neighbors and confirmed them as a vital link to French markets.

The Miami Indians, too, benefited from their contact with New France. Leaving Fort St. Louis in several waves during the 1680 , the Miamis established new settlements, first on the lower shores of Lake Michigan and then on the Maumee and Wabash Rivers. There they controlled a particularly rich field for hunting and trapping fur-bearing animals, and became prodigious traders in the European market. The political economy of the Miami tribes was fundamentally altered by their ties with French traders, and their level of fur production soon tested the capacity of the French market to absorb it. ${ }^{30}$ When Perrot first visited the Miamis in the 1660 s they were embarrassed that they had no beaver pelts to offer him; until that time, they had hunted beavers only for their

Adventure in Louisiana, trans. and ed. Richebourg McWilliams (Baton Rouge, 1953), pp. I 22-I 23; Blasingham, "Depopulation of the Illinois Indians," 376-377; Ramezay and Begon to the Minister, 7 Nov., I7 I5, in Reuben G. Thwaites, ed., Collections of the State Historical Society of Wisconsin, vol. XVI (Madison, I902), p. 332. The only study of slavery in French Canada is Marcel Trudel, L'Esclavage au Canada français: Histoire et Conditions de l'Esclavage (Quebec, 1960); although he did not examine records from the Illinois country or Louisiana, Trudel gives some idea of the magnitude of slaveholding in Canada (he has definitely identified a pool of 2,472 Indian slaves); links the slaves, where possible, to their tribal backgrounds; and describes the Canadian market in Indian slaves. He estimates that nearly $70 \%$ of Canada's Indian slaves were Pawnees, although it is difficult to be confident of that number since, by the third decade of the $I 8$ th century, the term "panis" had become a synonym for "slave" in New France.

29 Raymond E. Hauser, "Warfare and the Illinois Indian Tribe During the Seventeenth Century: An Exercise in Ethnohistory," The Old Northwest, Io (Winter 1984-1985), 378.

30 See, e.g., Jean Bochart de Champigny, "Mémoire pour le castor à Québec," 26 Oct. I694, quoted in Harold A. Innis, The Fur Trade in Canada: An Introduction to Canadian Economic History, rev. ed. (Toronto, 1956), pp. 70-7I. 
meat. ${ }^{31}$ They quickly learned the value Europeans placed on the animal's pelt, however, and just as quickly improvised a variety of commercial arrangements that allowed them to exploit European demand.

The economic benefits of the Miami alliance with New France comprised only one dimension in a larger pattern of aid and support; during the first several decades of the 18 th century they enjoyed an unusually strong position in their relations with the French. In part, this was because they occupied territory strategically situated in the borderlands separating French and British claims to territory in the Ohio Valley. As a result, the Miamis were recognized as vitally important to French efforts to control the central continent. This strategic centrality permitted the Miami tribes to dictate the terms of their relations with New France in important ways. For example, when they resisted the efforts of imperial administrators to make them settle near the trading post at Detroit, the governor of Canada had no choice but to approve the creation of two new trading posts on the Wabash and Maumee Rivers, in close proximity to the main towns of the Miami and Ouiatanon tribes. The Miami confederation also benefited, as did many of their neighbors, from French military support in their conflicts with other Indian groups. The most notable case was in the war waged against the Fox Indians. In that war most of the peoples of the western Great Lakes and Ohio Valley, including the Miamis and Illinois, succeeded in drawing the French into a military alliance to drive the Fox, Mascoutens, and Kickapoos from the lands around Detroit. In this conflict the Indians, much more than the French, forced events and dictated their outcome. ${ }^{32}$

In a variety of ways, the Illinois and Miami Indians thus managed to use the new opportunities presented by French explorers and traders as sources of renewed power and autonomy. These strategies of accommodation had their costs, but initially they offered important forms of protection to previously endangered communities.

\section{III}

The Iroquois raids that inflicted so much damage on the Illinois Indians were even more devastating for another Ohio Valley population. Early French accounts suggest that many Shawnee villages - I 5 in one source, 38 in another - were clustered south of the Ohio in the Cumberland

${ }^{31}$ La Potherie, "History of the Savage Peoples," in Blair, ed., Indian Tribes, vol. I, pp. $331-332$.

32 For the strategic importance of the Miami Indians, see Yves Zoltvany, "The Frontier Policy of Philippe de Rigaud de Vaudreuil, 1713-1725," Canadian Historical Review, $4^{8}$ (I967), 227-250; for Miami resistance to resettlement at Detroit, see Father d'Ave- 
River watershed; less reliable evidence also places some Shawnee communities north of the river in the upper valley. Some historians and archaeologists have argued that the Fort Ancient sites, which date from about 1400 to $165^{\circ}$ and share Mississippian traits, may in fact have been pre-contact Shawnee settlements. During the I660s and I670s, however, Iroquois warriors descended on Shawnee communities to inflict their characteristic terrors; by the early I 680 os the Shawnees had begun to splinter, abandon their homeland, and search for new and safer territories. One group of perhaps Iooo Shawnees migrated north, where in 1683 they were received by La Salle's traders and the Illinois and Miami Indians gathered around Fort St. Louis. Others moved east to the Carolinas, where they already had trading ties, took up residence on the Savannah River, and became known locally as the Savannah Indians. ${ }^{33}$

Soon the Shawnees at Fort St. Louis were on the move again. One group left the fort in 1688 or 1689 , and after a period of migration that apparently lasted several years, turned up in Maryland in 1692. The Maryland council was alarmed by the appearance of an unfamiliar group of Indians on the borders of its colony, particularly when they discovered that a Frenchman was traveling with them. Martin Chartier was a coureur de bois from the fort who had decided to throw in his lot with the Shawnee band; by the time they arrived in Maryland he was married to a Shawnee woman. The council quickly determined that Chartier was no spy, and soon he and the Shawnees had moved up the Susquehanna River into south central Pennsylvania where they settled the town of Pequea, apparently with the permission of the Unami Delawares who resided nearby. Two years later, in 1694 , the rest of the Shawnees at Fort St. Louis were invited to settle among another group of Delawares, the Munsees, who lived along the Delaware River in

naut to Cadillac, 6 June I702, Michigan Pioneer and Historical Society Collections, vol. XXXIII (Lansing, I904), p. I23; for Miami relocation and new posts, see Vaudreuil to Council, I 2 Dec. I7 I7, in Frances Krauskopf, ed., "Ouiatanon Documents," Indiana Historical Society Proceedings, vol. XVIII (Indianapolis, 1955), pp. r60-I6I; and for an account of the Fox wars generally, see White, Middle Ground, pp. I49-I75.

33 The most reliable account of the Shawnee migrations is in James Howard, Shawnee! The Ceremonialism of a Native Indian Tribe and Its Cultural Background (Athens, Ohio, 1981), pp. I-8 and following; a more comprehensive, but confusingly presented and occasionally inaccurate account can be found in Charles Hanna, The Wilderness Trail, 2 vols. (New York, I9II), vol. I, especially ch. 4. The population estimate is based on Franquelin's I 684 map of the fort, which gives a warrior count for each tribal group encamped in the vicinity. He estimates 200 Shawnee warriors, which would suggest a total Shawnee population at the fort of between 800 and I, 000 . For the Savannahs, see Verner Crane, The Southern Frontier, $1670-1732$ (New York, I98 I [orig. pub. 1928]), pp. I9-2I and following. 
northeastern Pennsylvania. The two Pennsylvania settlements became the core of a new Shawnee homeland; over the course of the next several decades most of the Shawnees on the Savannah River gradually migrated north to join their kinsmen. Initially the Shawnees were delighted with their new surroundings. One of their leaders told a Pennsylvania official that they were "happy to live in a Countrey at Peace, and not as in [those] Parts, where we formerly liv'd; for then upon our return from hunting, we found our Town surprized, and our women and children taken prisoners by our Enemies." 34

The Pequea Shawnees found themselves in the middle of a rapidly growing trading system in the Susquehanna Valley. It originated several years before their arrival, in part through the initiative of Jacques Le Tort, his wife Anne, and their son James, Huguenot refugees who fled from France to England in I685. In London, Le Tort met Sir Matthias Vincent, a partner in the New Mediterranean Sea Company. The company was founded by Dr. Daniel Coxe, a governor and great landholder of West Jersey, who hoped to exploit the Pennsylvania charter to bypass Iroquois control of the Great Lakes and engross the fur trade around Lake Erie - the "New Mediterranean." William Penn granted Coxe, Vincent, and their associates 100,000 acres within his colony in exchange for their promise to establish a new trading venture. Vincent then hired Le Tort to manage his estate within the company's grant, and the Le Torts left for Pennsylvania. In the meantime, however, the scheme was blocked by the Albany traders, who were well-represented in the court of King James (since James was New York's proprietor), and who depended on the Iroquois trade for their livelihood. Coxe's company collapsed; in place of his grand enterprise, he hired Le Tort simply to act as his private agent in the Pennsylvania Indian trade. ${ }^{35}$

Le Tort quickly found that the Schuylkill River trade with the Delaware Indians offered few opportunities to a newcomer; it was dominated by a host of well-established Swedes, Germans, and Englishmen. At about this time he crossed paths with Peter Bizaillon, an experienced coureur de bois who had served with Henri Tonti, lived in the Illinois country, and traveled the Mississippi. Bizaillon guided Le Tort on an ex-

34 William Hand Browne et al., eds., Archives of Maryland, 63 vol. (Baltimore, I883I9I 5), vol. VIII, pp. 341-345; Peter Schuyler to Iroquois, 6 Feb. I694, and Arent Schuyler's journal, 10 Feb. 1694, in E. B. O'Callaghan and Berthold Fernow, eds., Documents Relative to the Colonial History of the State of New York, I 5 vols. (Albany, I 8 56-1 887) [hereafter NYCD], vol. IV, pp. 90, 98-99; Minutes of the Provincial Council of Pennsyvlania, I6 vols. (Harrisburg, I 838-1853) [hereafter Pa. Col. Recs.], vol. II, p. 388.

${ }^{35}$ Evelyn A. Benson, "The Huguenot Le Torts: First Christian Family on the Conestoga," Journal of the Lancaster County Historical Society, 65 (196I), 92-105. 
traordinary westward odyssey. They followed the Schuylkill and Susquehanna Rivers and their tributaries until they could portage to the Allegheny, which flows into the Ohio; they continued to the Mississippi, where they turned upstream and paddled a short distance up the Missouri before retracing their steps to the Schuylkill. Along the way they reportedly contacted more than forty Indian nations, "who all treated them very kindly and gave them many furrs." It was a long and arduous trip (some historians have dismissed accounts of it as too fantastic to believe), but Le Tort was not the first to take it - the Shawnees, Chartier, and Bizaillon had all followed essentially the same route - and he would be by no means the last. ${ }^{36}$

Shortly thereafter the Le Torts moved to the Susquehanna Valley, where they were soon trading with "strange Indians." Their mysterious contacts, many of them with French-allied tribes, aroused suspicion (and probably envy) among their competitors in Pennsylvania. A group of fellow traders petitioned the Governor's Council in I694 to bar the Le Torts from trading "in remote and obscure places with the nativs." Instead, the council required Le Tort to take an oath of loyalty and to "acquaint the governm[en]t with all matters hee can hear of or observe concerning the Natives \& the enemies of the countrie." 37

Two years later Le Tort died at sea, but by that time he had drawn a nucleus of traders to the Susquehanna Valley that included his wife and son, Bizaillon, and John Dubrois, another Huguenot in Le Tort's employ. Thus the Pequea Shawnees discovered congenial trading contacts in their new home - contacts who were familiar with the west and who even spoke French. The Le Torts and their associates had established a tantalizing, but still tenuous and irregular, trade; the Shawnees helped put their business on a more reliable footing, one built on contacts between partners close at hand. The Shawnees were ideally suited to the developing Susquehanna Valley trade: they knew the hunting grounds of

36 Coxe reportedly gave William Penn a journal and map of the trip in I693. In I7I9 he presented a memorial to the Board of Trade that described the expedition; though its credibility has been questioned, the accuracy of its descriptions and Le Tort's association with Bizaillon make Coxe's claims plausible. The memorial appears, along with a skeptical assessment, in Clarence Alvord and Lee Bidgood, The First Explorations of the Trans-Allegheny Region by the Virginians, I650-I674 (Cleveland, I912), pp. 23 I-249; quote: p. 245. For more positive assessments of Coxe's claims, see Benson, "Huguenot Le Torts," pp. 99-I00, and Francis Jennings, “The Indian Trade of the Susquehanna Valley," Proceedings of the American Philosophical Society, I Io (1966), 409-4IO. For extracts of the memorial and related documents, see also Albright Zimmerman, "Daniel Coxe and the New Mediterranean Sea Company," Pennsylvania Magazine of History and Biography, 76 (1952), 86-96.

37 Council minutes, 6 Feb. I694, Pa. Col. Recs., vol. I, pp. 435-436. 
the west; they had lived and traveled in the Ohio Valley. Moreover, in contrast to the Delawares and Iroquois whose experience with the fur trade centered on beavers, the Shawnees were seasoned deer hunters; those who had traded in the Carolinas had even hunted deer and prepared hides for the transatlantic market. While the founders of the New Mediterranean Sea Company envisioned the Susquehanna Valley as a conduit to the north, where Pennsylvania traders might challenge the Iroquois' control of the Great Lakes beaver trade, the westward-oriented trading system that developed in the lower Susquehanna specialized in deer hides rather than beaver pelts and opened the rich game populations of western Pennsylvania and the upper Ohio Valley to the English market for the first time.

James Logan quickly emerged as the Philadelphia merchant most closely identified with the Susquehanna trade. Logan was a precocious young Scotsman of twenty-five, just embarking on a career in trade, when he caught William Penn's eye and was recruited to accompany the proprietor to his colony in 1699 . Penn made him his personal secretary and agent in colonial affairs. Logan soon became a dominant figure in Pennsylvania's public life, and usually appears in historical accounts as the prominent merchant and leading intellectual light that he eventually became. But focusing on the older Logan, a man of accomplishments, wealth, and ease, obscures the ambitious achievements of his first years in the colony, when he successfully wed his desire for personal wealth with the pressing need to grasp and shape affairs on Pennsylvania's western frontier. ${ }^{38}$

Though he began his private career in Pennsylvania as a planter, Logan soon became a factor, or wholesaler of agricultural products, on behalf of his neighbors. He specialized in buying, cutting, packing, and shipping tobacco; at the same time he entered into the dry goods trade, selling manufactured products from England back to the planters in return. But his returns were marginal, and by 1707 his creditors were worried about his prospects. Sometime in the second decade of the century he discovered the Indian trade, and through a patchwork of transactions he gradually shifted his attention to the west. By 1717 the trade

38 Though various works have focused on certain aspects of Logan's career, he remains a neglected subject. Brief sketches can be found in Wilson Armistead, Memoirs of James Logan (London, I85 I) and Irma Jane Cooper, The Life and Public Services of James Logan (New York, I92I); his early career is considered in Joseph Johnson, "A Statesman of Colonial Pennsylvania: A Study of the Private Life and Public Career of James Logan to the Year 1726" (Ph.D. diss., Harvard Univ., I943); and his role in shaping provincial culture is treated in Frederick Tolles, James Logan and the Culture of Provincial America (Boston, 1957). 
in skins and furs dominated his account book; in that year, his principal suppliers were Anne and James Le Tort, Peter Bizaillon, Joseph Smith, Martin Chartier, and John Cartlidge - names that would persist in all of Logan's surviving financial records. Logan's personal entry into the fur trade coincided with the rise of fur and skin exports in Pennsylvania's commerce with London. Customs records indicate that the volume of the trade fluctuated widely from I699 to I7I3: although there were three years in which more than $£_{1000}$ worth were shipped, there were also three years in which the total value of the trade was less than $£_{\text {I }}$ oo. In I7I 4 these figures began to stabilize. Over the next ten years the annual value of fur and skin exports never fell below $£_{I 000}$, and it averaged more than $£_{I 75}$ o per year (Fig. 2). ${ }^{39}$

Logan soon controlled the Susquehanna trade, and the trading cycle followed an increasingly predictable pattern. Logan delivered merchandise to the colonist-traders at the town of Conestoga, a short distance north of Pequea. The traders received the goods on credit, and then delivered them, again on credit, to their Indian customers. The Indians carried away their merchandise and went west to winter hunting camps, which were strung across western Pennsylvania as far west as the Allegheny and the headwaters of the Ohio. The Indians traded mostly for durable goods; cloth items like strouds, blankets, duffels, and "half thicks" predominated, along with decorative items like gartering and silk handkerchiefs. Iron mouth harps were also in high demand, as were rings, beads, steels and flints, vermillion, and pipes. Guns were not yet articles of trade in Pennsylvania, and rum changed hands in only token amounts - indeed, the small amounts that Logan shipped may have been kept by the traders for their own consumption. In the spring Indian hunters returned from their camps with the fruits of their winter hunt primarily deerskins and bearskins, with a few pelts from smaller animals like beaver. The colonist-traders then carried the packs of furs to Logan's post at Conestoga, where they were loaded on a wagon, owned by Logan, and shipped to Philadelphia at the traders' expense. In the process, nearly every trader at Conestoga fell chronically into Logan's

39 James Logan Receipt Book, I702-1709, Logan Papers, Historical Society of Pennsylvania, Philadelphia; Logan to John Askew, Aug. 1706 and 2 Jan. I707, James Logan Letter Book, Logan Papers, vol. II, HSP; James Logan Account Book, I 7 I 2-1 720 , Logan Papers, vol. IX, HSP; Stephen H. Cutcliffe, "Colonial Indian Policy As a Measure of Rising Imperialism: New York and Pennsylvania, I700-1755," The Western Pennsylvania Historical Magazine, 64 (I981), 240-242, Table I: "Fur and Skin Exports from New York and Pennsylvania to London by Constant Value in $£$." The figures are based on a constant value to correct for price fluctuations, so the table provides a roughly accurate gauge of the number of skins and furs shipped. 


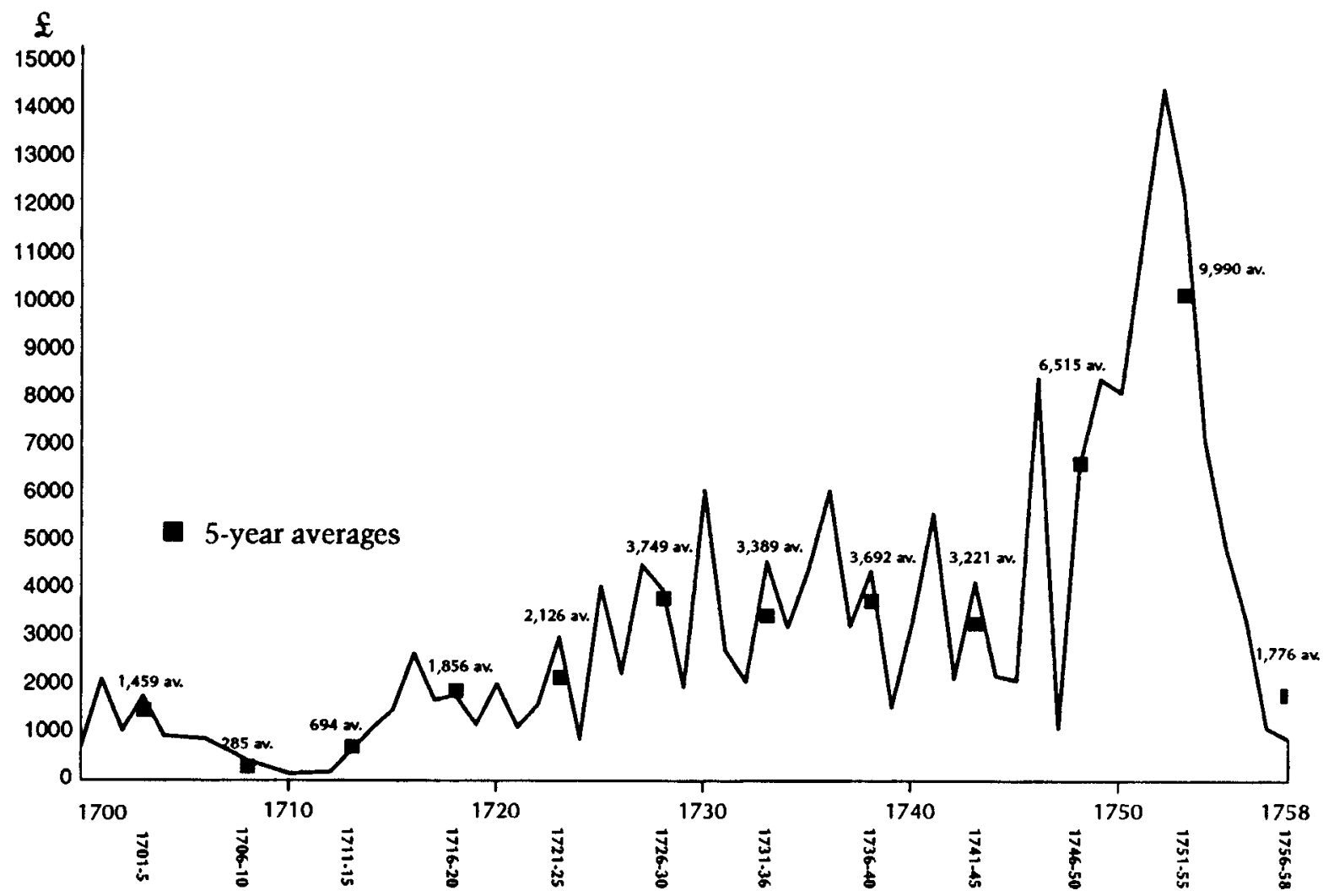

Figure 2. Fur and skin exports from Pennsylvania to London (constant value). Source: Stephen H. Cutcliffe, "Colonial Indian Policy As a Measure of Rising Imperialism: New York and Pennsylvania, 1700-1755," The Western Pennsylvania Historical Magazine, 64 (1981), 237-268, Table 1 . No data was available for 1705 and 1712. 
debt; by the mid-I720s many carried debts of between $£_{300}$ and $£_{65} \circ$ apiece. ${ }^{40}$

While Logan the merchant profited handsomely from the trade, Logan the public official gained a valuable window into Indian affairs through his connections with the Susquehanna traders. He turned many of the traders into unofficial deputies of the governor's council, asking them to serve as interpreters, informants, and even, occasionally, as informal diplomats in intercultural relations. In return, Logan favored many of the most cooperative traders with generous grants of land from the colony, as well as with other forms of support. ${ }^{41}$

With the opening he gained from the traders, Logan became the chief architect of Pennsylvania's Indian policy in the west. His partner in this process was the Iroquois confederacy. The Iroquois interest in the lower Susquehanna Valley was rooted, perhaps unsurprisingly, in conquest. In the middle of the 17 th century the region was controlled by the Susquehannocks, who were regarded by early English visitors as one of the most powerful nations on the continent. (In I624 John Smith wrote that they were so "great" and "well proportioned" that "they seemed like Giants to the English.") But beginning in the 1660 s the Susquehannocks were victimized by a series of Iroquois attacks; in 1674 they were forced south into Maryland, where a few years later they were caught in the backlash against Bacon's Rebellion in Virginia. Reeling with defeats, the surviving Susquehannocks found refuge in various Iroquois villages, and for nearly two decades the lower Susquehanna was largely unoccupied. In about $\mathrm{I} 690$ a remnant band of Susquehannocks, accompanied by a

${ }^{40}$ For accounts with traders see James Logan Ledger, I720-1728, Logan Papers, vol. X, HSP; for breakdown of merchandise see James Logan Day Book, 5 Sept. 1722-16 Jan. I723, Logan Papers, HSP, and Logan's Account Book, I 7 I 2-I 720 , Logan Papers, vol. IX, HSP. For Logan's rise in the Indian trade see also Evelyn Benson, "The Earliest Use of the Term 'Conestoga Wagon," Papers of the Lancaster County Historical Society, 57 (1953), I09-1 I9, and Jennings, "Indian Trade."

41 Interpreters: see, e.g., Pa. Col. Recs., vol. II, pp. 388-39I; vol. III, pp. 45-49, 78-80, 92-98, I23-I 25; informants: e.g., Pa. Col. Recs., vol. II, pp. I3 I, I45, I 2 I-I22; vol. III, pp. 295-298; diplomats: Logan to Bizaillon, 28 Oct. 1713, Logan Papers, vol. III, p. 239, American Philosophical Society, Philadelphia. Land grants: see surveys in the Taylor Papers, vol. XII, nos. 2399, 2426, and vol. XIII, no. 273 I, HSP; William Egle, ed., Pennsylvania Archives, 2nd Ser., 19 vols. (Harrisburg, I874-1893), vol. XIX, p. 496; James Steel's Letter Book, p. 83, Logan Papers, HSP; and Jennings, "Indian Trade," p. 4 18. This argument is developed in more detail, and the materials listed in this note are discussed more fully, in Eric Hinderaker, "The Creation of the American Frontier: Europeans and Indians in the Ohio River Valley, I673-1800" (Ph.D. diss., Harvard Univ., I99I), pp. I86-191. See also the parallel discussion in Jennings' "Indian Trade," which stresses more than my account Logan's efforts to enrich himself personally through his relations with the traders. 
group of Iroquois overseers from the Seneca tribe, returned to found a village at the mouth of Conestoga Creek; as a result of their location the combined Seneca/Susquehanna group was known by colonists as the Conestoga Indians. During the next several decades, as Iroquois war parties turned south, refugees streamed north out of the backcountry of Virginia and the Carolinas to take up residence in Iroquoia. Conoys, Tutelos, Nanticokes, and Tuscaroras, among others, followed the Susquehanna River toward Iroquois country; some settled for a time in or around Conestoga, creating what one historian has described as "a veritable united nations of Indians" there. ${ }^{42}$

The Conestoga Indians and the other southern refugees on the Susquehanna were Iroquois dependents; the Shawnees, on the other hand, had an uneasy, ill-defined relationship with the Iroquois. They considered themselves guests and allies of the Delawares, not the Iroquois. By I 700 a shared Shawnee-Delaware town named Paxtang had been settled on the Susquehanna, and the Shawnee groups on both the Susquehanna and the upper Delaware Rivers developed close political and kinship ties with the Delawares among whom they lived. The political relationship between the Iroquois and Delawares is itself problematic and controversial. It is clear that the Delawares recognized a debt of tribute to the Iroquois that dated to sometime in the 17 th century, but it is equally clear that the Delawares were not refugees - they still retained control of their territory along the Delaware River - and thus they were not in the same position of complete subjection to the Iroquois council that the refugee groups on the Susquehanna were. ${ }^{43}$ Nevertheless, in a

42 John Smith, Generall Historie of Virginia, New England, and the Summer Isles ( (1624), in Edward Arber, ed., Travels and Works, 2 vols. (New York, I966 [orig. pub. I910]), vol. I, p. 350 and following. The best discussion of these displacements and migrations is in Barry C. Kent, Susquebanna's Indians, The Pennsylvania Historical and Museum Commission, Anthropological Series, no. 6 (Harrisburg, I984). Quote: Francis Jennings, "Iroquois Alliances in American History," in Jennings et al., eds., The History and Culture of Iroquois Diplomacy (Syracuse, r985), p. 41.

43 Both the Delawares and, after their arrival in Pennsylvania, the Shawnees, formally acquiesced to the Iroquois in political affairs; for a description of a Delaware mission to offer tribute, see $\mathrm{Pa}$. Col. Recs., vol. II, p. 546-549; for a sketchy account of the Iroquois settlement with the Shawnees, ibid., vol. II, pp. I45, I 55, I 58-1 59. The precise terms of these relationships have been a subject of much controversy among historians; for various interpretations, see Anthony F. C. Wallace, "Woman, Land, and Society: Three Aspects of Aboriginal Delaware Life," Pennsylvania Archaeologist, I7 (1947), I-35; Francis Jennings, "The Delaware Interregnum," Pennsylvania Magazine of History and Biography, 89 (1965), 174-198, and The Ambiguous Iroquois Empire: The Covenant Chain Confederation of Indian Tribes from its Beginnings to the Lancaster Treaty of 1744 (New York, I984), pp. 2I4-219, 30I-303. My view is that both groups recognized a formal obligation of tribute, but did not understand that obliga- 
process that will be described in more detail in chapter three, beginning in I72I Logan and the Iroquois placed increasing pressure on the Indians of Pennsylvania to accept the Iroquois as their spokesmen and political superiors in all their dealings with the colony.

Beginning in the mid-1720s, parties of Shawnees and Delawares chose to leave the Susquehanna Valley to escape domination by Pennsylvania and Iroquois officials. They moved to a series of new villages, most of which grew up on the sites of old winter hunting camps, on the Allegheny and upper Ohio Rivers. In 1725 Pennsylvania's Shawnee and Delaware Indians each had one village site west of the Susquehanna Valley: Opessa's Town was a Shawnee settlement on the upper Potomac, while the Delaware town of Kittanning stood on the Allegheny River a short distance above the headwaters of the Ohio. During the next several years Shawnees and Delawares began to move west in larger numbers. ${ }^{44}$ The migratory stream accelerated rapidly after 1728 , and by I73 I more than half a dozen new towns had already been founded on the Allegheny and upper Ohio Rivers.

Pennsylvania's Governor Patrick Gordon, alarmed by the rapid outmigration of the colony's Indian population, questioned three traders late in I73 I who were familiar with the developing cluster of western settlements. Already, the traders estimated that between four and five hundred men, many with families, had moved west. The principal Delaware towns, according to Gordon's informants, were Kittanning, Kiskimenitas Town, Shannopin's Town, and Assunepachla, or Frankstown. The Shawnee settlements, in addition to Opessa's Town, included Black Legs Town, Conemaugh Town, James LeTort's town, and Ohesson, which lay on the Juniata River midway between the older Susquehanna settlements and the new ones on the Allegheny and Ohio. ${ }^{45}$

tion to entail abject political subjection. It was not until the 1720 s that the Iroquois council tried to parlay their vague authority over the Delawares and Shawnees into absolute political superiority; see, e.g., the letter from several Shawnee chiefs to Governor Gordon claiming that the Iroquois first put "pettycoats" on them, an act that implies political subjection, in about 1726: Samuel Hazard, ed., Pennsylvania Archives [rst Ser.], I 2 vols. (Philadelphia, I 852-1 856 ), vol. I, pp. 329-330.

44 James Logan dated the first removal of members of these tribes to about 1724 ; see his letters to Gov. Clarke, 4 Aug. 1737, and Gov. Gooch, I I May 1738, Logan Papers vol. IV, pp. 13-16, APS.

45 Examinations of Jonah Davenport, James Le Tort, and Edmund Cartlidge, 29 Oct. and 7 Dec. I73I, Pa. Arch. [Ist Ser.], vol. I, pp. 299-302, 305-306. The best available map for locating these towns is Barry C. Kent, Janet Rice, and Kakuko Ota, "A Map of I 8th Century Indian Towns in Pennsylvania," Pennsylvania Archaeologist, 5 I (198I), $\mathrm{I}-\mathrm{I} 8$ and endpaper. See also William Scull's excellent map of the colony published in 1770 . 
This migration stream would reach a flood stage by midcentury. The earliest Shawnees and Delawares were joined by successive waves of other Indian migrants: additional Shawnee and Delaware bands, many of whom had lost their Pennsylvania lands by treaty and sale to the colony; other members of the Iroquois protectorate, including Mahican refugees who had been pushed steadily westward from their original homelands in New England and New York, and bands of southern Indians, especially Nanticokes, who were driven off their lands by Cherokee and Catawba attacks; and a growing population of Iroquois hunters. Ostensibly the function of the Ohio Iroquois was to oversee the other Ohio Indians; Queen Aliquippa was the first Iroquois-appointed overseer for the region. But in reality, Aliquippa's Town was primarily a hunting and trading town like all the others. Queen Aliquippa was surrounded by young men who had come west for better access to game, much as the Shawnee and Delaware hunters had. In Aliquippa's Town originated the Ohio Valley band known as the Mingos, western Iroquois (mostly Senecas) who became notorious among colonial officials for their troublesome independence from the Iroquois council at Onondaga. ${ }^{46}$

For Pennsylvania officials and Iroquois leaders alike, the westward migration that began in the 1720 s threatened the order they were trying to impose on Indian affairs. Above all, Pennsylvania officials feared that the western Indians might unite with the French in opposition to the colony's interests. But when they encouraged the Shawnees to return to the Susquehanna Valley and offered them a parcel of land as an enticement, Opakethwa, one of a new generation of Shawnee chiefs who reveled in their newfound autonomy, asked that the land be held for them in trust but insisted that, in the West, they could "live much better ... than they possibly can any where on the Sasquehannah." He tried to ease the governor's fears by pointing out that, in moving west, "they did a Service to this Province, in getting Skins for it in a place so far remote." 47

46 For a more detailed discussion of this migration see Michael McConnell, A Country Between: The Upper Obio Valley and Its Peoples, I724-1774 (Lincoln, NE, 1992), ch. I. McConnell overemphasizes the communal and tribal cohesion of these migrations, in my view, and underestimates the extent to which Seneca villages in the Ohio Valley were populated by Indians from various backgrounds, but his is nevertheless an invaluable account.

47 The Shawnees were invited to send a delegation to Philadelphia in the spring of 1732 by Governor Gordon, and in response he received vague assurances in a letter from five chiefs that some Shawnee representatives would visit Philadelphia sometime during the summer; see Pa. Arch. [rst Ser.], vol. I, pp. 329-330. Four delegates - Opakethwa, 
When a direct appeal to the Shawnee leaders failed, the governor and his advisers still hoped that the Iroquois council might intervene to stem the tide of outward migration among the colony's Indians. The Iroquois reported that they had tried to persuade both Shawnee and Delaware leaders to "come back from the Ohio," but persuasion had so far proven insufficient. Believing that the Iroquois exercised "absolute Authority" over the Indians of Pennsylvania, the governor pressed them to enforce their order. When the Iroquois finally did try to pressure the Ohio Indians to return to Pennsylvania, a colonial official reported that the Iroquois' "Great Men received ... ill usage instead of the expected success." Indeed, a Shawnee faction took offense at the arrogance of one of the visiting chiefs, and after the Iroquois delegation departed they traveled to Iroquoia, murdered the despised leader, and then fled down the Ohio River to found a new town at the mouth of the Scioto River the town that would later become the center of Shawnee settlement in the Ohio Valley. ${ }^{48}$

The hierarchical structure of Indian diplomacy that leaders of Pennsylvania and the Iroquois were trying to impose on the colony's Indians paralleled the structure of the Covenant Chain, the diplomatic system that connected the Iroquois with New York. The metaphor sounds egalitarian, but within the logic of the Covenant Chain the first link was the strongest; the Iroquois exercised preeminent authority over every Indian group subject to their leadership. Instead of accepting the Covenant Chain, which would have placed them at the bottom of this hierarchy, Shawnee leaders sought to distance themselves from Pennsylvania and the Iroquois. To this end they established ties with New France - not in the interest of replacing one overlord with another, but to facilitate a play-off relationship that would balance their own interests between those of the European powers. In the early I730s the Shawnees met with traders and colonial officials from New France, and soon Shawnee delegates visiting Philadelphia warned that they had now moved so far west that they were in danger of "going over to the French" unless Pennsylvania offered them arms and ammunition. Governor George Thomas despaired of the Shawnees' "Inconstancy." Although he acknowledged that Pennsylvania's "most valuable Trade for Skins is with them," he feared that the Shawnees had become ungovernable. Clearly, the Iroquois were not the answer; "the closer our Union has been with

Opakeita, and two younger men - finally arrived in the city at the end of September; for their visit, see Pa. Col. Recs., vol III, pp. 49 I-496; quotes: pp. 494-495.

$48 \mathrm{~Pa}$. Col. Recs., vol. III, pp. 426-429, 464-483; Logan to Gooch, I I May 1738, Logan Papers, vol. IV, pp. 13-16, APS; Pa. Col. Recs., vol. III, pp. 607-609. 
the Six Nations," he noted, "the greater distance they [the Shawnees] have kept from us." 49

In contrast to the desire of colonial officials to dominate and control the Shawnees, the Shawnees sought a middle way that would allow them to develop roughly equivalent diplomatic and economic ties with each imperial power. Leaders in Philadelphia and Iroquoia imagined the western Indians as the final link in a chain that began with them; the Shawnees put forward an alternative metaphor, one that placed them at the center of an international trading nexus. Shawnee spokesmen admitted to the governor of Pennsylvania that they had established ties with New France from their new base in the Ohio Valley, but insisted that this did not imply an intention to "leave their brethren the English, or turn their backs upon them." On the contrary, Opakethwa claimed that the governor of New France himself had advised the Shawnees to maintain ties with the English, since they "were much better furnished with Cloathing, and other things necessary for the Indians, than his people were"; furthermore, according to Opakethwa, the French governor hoped "that in time the French and English Traders would meet at Allegheny, exchange goods, and trade together." This was a blatant misrepresention of Governor Beauharnois' wishes; he consistently and emphatically urged the Ohio Indians to sever their ties with the English. ${ }^{50}$ But Opakethwa's misrepresentation perfectly described the relationship the Shawnees hoped to cultivate with the two European powers. By establishing economic ties with both France and Britain and avoiding diplomatic domination by either, they sought to maximize their independence and power.

The newfound political leverage of the Shawnees and their western neighbors was complemented by the growth of their trade. The move west lifted earlier constraints on the process of hunting for the market. While they lived on the Susquehanna, where game was scarce by the beginning of the 18 th century, Indian hunters had to travel many miles through rough terrain to their winter camps and then carry the furs and skins they collected back to the Susquehanna trading posts. Since they did not employ pack animals, the practical limit on the number of skins

49 For the Covenant Chain see especially Richter, Ordeal of the Longhouse, Jennings, Ambiguous Iroquois Empire, and Richard Aquila, The Iroquois Restoration: Iroquois Diplomacy on the Colonial Frontier, $1701-1754$ (Detroit, 1983); Council minutes, 10 Aug. I737, Pa. Col. Recs., vol. IV, pp. 233-235; Speech of Gov. Thomas to Assembly, 3 I July I 744, ibid., vol. IV, pp. 737-740.

50 $\mathrm{Pa}$. Col. Recs., vol. III, pp. 491-496; Beauharnois to the Minister, I5 Oct. I732, and Indian Council speeches, 1732 , in Sylvester Stevens and Donald Kent, eds., Wilderness Chronicles of Northwestern Pennsylvania (Harrisburg, I94I), pp. 5-I I. 
they traded was the number they and their families could transport. This pattern kept the volume of the trade quite modest, and guaranteed that hunting for the market would never be more than a sidelight to the economic activities of the Susquehanna Indians.

As Indians moved west, the structure of the trade was revolutionized and its volume jumped immediately and dramatically (Fig. 2). The burden of transporting skins, furs, and merchandise began to fall on the Pennsylvania traders, who were forced to travel to the western country to trade with the Indians. ${ }^{51}$ This change demanded a more vigorous and capital-intensive form of business enterprise, fraught with risk. Traders used pack animals, employees, servants, and slaves to bear the added physical burdens, and took on partners to share the financial ones. These requirements made the Indian trade more challenging, but as its volume increased it also became potentially more lucrative. For the Indians, the change brought a new level of affluence and a new importance as producers and customers in the British commercial system. The western Shawnees and Delawares, along with the other groups being drawn into the trading network they pioneered, became Pennsylvania's most important source of deerskins and furs. Game was abundant, since the valley lands had been left largely uninhabited for two generations after the Iroquois wars; thus, when a Shawnee band settled near the mouth of the Scioto River they gave it a name that signified "Hairy River," because "when they first came to live here, deers were so plenty, that in the vernal season, when they came to drink, the stream would be thick of hairs." 52

Although these developments were intimately tied to the Ohio Indians' growing reliance on transatlantic markets, they seemed to create a renaissance of traditional pursuits. The first several decades following the westward migration were halcyon days for previously embattled hunters and warriors. Both the Shawnees and the Delawares had struggled with displacement from traditional territories, shrinking success in hunting, and periodic failure and frustration in warfare. In the Ohio Valley they entered an expansive territory, free of the encroachments of settlers and their livestock, where they could spread out in search of ideal village sites. ${ }^{53}$ Women planted extensive fields without worrying

51 This change forced most of the Susquehanna traders out of the business. Of the twenty traders who were operating in the Allegheny and Ohio River towns and were identified by name in the Letter Respecting Traders, I May I732, Pa. Arch. [Ist Ser.], vol. I, p. 425 , only four were doing business with Logan a decade earlier.

52 David Jones, A Journal of Two Visits Made to Some Nations of Indians on the West Side of the River Obio, in the Years $1772-1773$ (New York, I 865 [orig. pub. 1774]), p. 46.

53 On colonial livestock in Indian fields see, e.g., Pa. Col. Recs., vol. II, p. 554; vol. III, pp. 
whether pigs and cattle would trample and forage in them, while men enjoyed unparalleled opportunity as hunters and traders. ${ }^{54}$ For a time, the new communities on the Allegheny and Ohio thrived.

\section{IV}

French and British officials envisioned the Indian trade as a zero-sum competition for furs and skins, for trading partners, and by extension for neatly defined territorial claims. In practice, patterns of trade in the Ohio Valley did more to confuse than to clarify imperial pretensions to power. The region's commercial system developed according to a logic all its own - one that no administrator of empire could wholeheartedly endorse. As Indians and colonists pursued their own ends, the empires, contrary to all expectation, became the pawns in a complex of processes that neither could do much to control. While colonial officials tried to keep the British and French spheres in the Ohio Valley separate and distinct, the region's geographic unity and the dynamics of commercial expansion tended to blur the boundaries of national difference. Trading ties crossed artificially defined boundaries and increasingly knit the entire valley together into a single, unified commercial zone. The more trade refused to conform to national interests, the more aggressively French and British officials pushed to clarify imperial boundaries in the Ohio Valley, a process that culminated in the outbreak of the Seven Years' War. In the end, the struggle to create exclusive zones of commer-

$49,323-324$. On the problem of encroachment more generally see especially the controversies over Conestoga and the Tulpehocken lands, in ibid., vol. III, pp. 216 and following and vol. III, p. 3 I 8 and following. For a fuller discussion of livestock, fences, and Indian lands, see William Cronon, Changes in the Land: Indians, Colonists, and the Ecology of New England (New York, 1983), pp. 127-1 56, and for livestock in particular as a source of intercultural conflict see Virginia DeJohn Anderson, "King Philip's Herds: Indians, Colonists, and the Problem of Livestock in Early New England," WMQ, 51 (1994), 60I-624.

54 On the tendency for settlement to sprawl and, particularly with the Delawares, for villages to be small and dispersed, see, e.g., Christopher Gist's first journal, I750-175 I, in Lois Mulkearn, ed., George Mercer Papers Relating to the Ohio Company of Virginia (Pittsburgh, 1954), pp. 99-1 14, in which he recorded visits to a dozen Indian communities. Of these, half were Delaware settlements, and of the four whose size he noted, the largest contained only twenty families. Another included half that many, and two were tiny villages of only four to six families, or perhaps thirty residents. The principal Shawnee towns, which tended to be much larger, were noteworthy for the size and productivity of their fields; the Governor General of New France called the Shawnees "an industrious tribe, cultivating much land." Beauharnois and d'Aigremont to Maurepas, I Oct. 1728, Stevens and Kent, eds., Wilderness Chronicles, pp. 3-4. 
cial activity in the Ohio Valley only clarified the inherent limitations of a colonial system conceived along these lines.

Ironically, the Ohio Valley trade was not particularly profitable for either empire. It nevertheless drew each into a complex tangle of Indian alliances, and once they were involved they had no choice but to follow out the logic of these connections. Thus when the Illinois and Miami trade first opened to French markets, the result, measured purely in economic terms, was disastrous. On the one hand, the fermiers who held the royal monopoly in furs could not begin to absorb the sudden dramatic increase in the supply of beaver pelts, and during the first two decades of the 18 th century enormous overstocks of furs slowly mouldered and rotted in Paris warehouses as hatmakers struggled to put them to profitable use. On the other hand, the beaver pelts acquired from the Ohio Valley were neither as thick nor as well-prepared as those traded further north. In order to compensate for the loss of quality associated with the Ohio Valley trade, the French government was forced to create a grading system that distinguished between higher- and lowerquality pelts and valued them accordingly. ${ }^{55}$

The colony of Pennsylvania, and the British empire it was supposed to serve, also benefitted in only limited ways from the western trade. Since trade was not conducted through monopolies, as it was in New France, neither colony nor empire collected fees from traders. In the decentralized system of enterprise favored by the British, benefits accrued to the crown less directly, through customs revenues and the growth of imperial markets. In the grand scheme of 18 th-century empire, the Indian trade was a minor contributor to Britain's national wealth; and within Pennsylvania's robust commercial economy it was a small sidelight to the principal channels of trade. ${ }^{56}$ The risks of the Indian trade, extraordinary even by colonial standards, meant that a few merchant firms emerged as specialists that dominated the field, while the most established Philadelphia partnerships generally chose to steer clear of such an uncertain enterprise. ${ }^{57}$ Even on the eve of the Seven Years' War, when the volume of skins and furs exported from Pennsylvania reached unprecedented heights, the risks of the Ohio Valley trade were so high that very few participants could consistently make it pay. Nevertheless, offi-

55 Innis, Fur Trade in Canada, pp. 63-73.

56 Alice Hanson Jones, Wealth of a Nation to Be: The American Colonies on the Eve of the Revolution (New York, I980), Table 2.8, "Major Commodity Exports by Region, I770," p. 48.

57 On risk generally see Thomas Doerflinger, A Vigorous Spirit of Enterprise: Merchants and Economic Development in Revolutionary Philadelphia (Chapel Hill, 1986), especially pp. I35-164; and on the Indian trade in particular, pp. I48-1 51 . 
cers of both empires invested untold time, energy, and resources in the effort to sustain and expand the Indian trade, because they equated trading alliances with imperial ascendancy. To compete with one another, the French and British empires supported trade networks whose dynamics ultimately threatened to ruin them both.

But if the economic benefits of the interior Indian trade were questionable when viewed from an imperial perspective, many promoters and traders were enthusiastic about its possibilities. The alluring myth of American abundance, even the intoxicating attractions of remote and exotic regions, were enough to draw certain kinds of adventurers into the field to test their fortunes and seek opportunity in an often uncomprehended enterprise. Entering the fur trade, like playing a lottery, was a gamble that not everyone could hope to win; nevertheless, with the right combination of skill and luck, some traders might do remarkably well. In the French empire the activities of the coureurs de bois have been relentlessly romanticized, until they have taken on legendary proportions in early American history. Britain's middle colonies, and especially Pennsylvania, gave rise to their own class of strenuous traders, who also expended enormous effort and took great risks in the pursuit of profits and adventure. Though their occupations were unusual, the peripatetic Indian traders were responding in their own way to a universal European fascination with the abundance of American resources. Drawn to the far margins of the known world, they were frequently entranced and just as often deceived - by the apparent prospect of easy and unlimited wealth. The remote, temperate, and beautiful Ohio Valley was a particularly strong magnet for traders in search of such esoteric opportunity.

The coureurs of New France first entered the region from the Great Lakes, following (and in a few cases apparently even anticipating) the explorations and discoveries of Marquette and La Salle. While a restrictive licensing system permitted a small number of colonists to carry on a trade in furs by permission of the crown, other coureurs who entered the field in the last two decades of the 17 th century did so essentially as outlaws. This status perhaps contributed to their tendency toward creative freelancing as commercial agents. From a surprisingly early date, coureurs de bois from the Illinois country began to experiment with trading routes to the English colonies on the Atlantic seaboard as alternatives to the much nearer French outposts; their experiments were further encouraged when Louis XIV temporarily outlawed the activities of coureurs altogether in $1696 .{ }^{58}$

58 The 1696 edict is printed in part in NYCD, vol. IX, p. 636; for its context, see William Eccles, The Canadian Frontier, 1534-1760 (New York, 1969), pp. 125-1 28. 
Martin Chartier and Peter Bizaillon were both introduced to the Illinois country as associates of La Salle and Tonti, but soon helped pioneer trading routes that carried furs and skins from French-allied Indian tribes into English markets. They were not alone. In the first place they apparently had collaborators, especially among the Miami Indians, where Bizaillon's brother Michel resided as a trader and probably helped to facilitate trade contacts between the Miami Indians and the Le Tort group. In I 7 I4 an official of New France lamented to his superior that Bizaillon and his associates were leading "a life not only scandalous but even Criminal in many ways" among the colony's Indian allies in the Ohio Valley. 59

At roughly the same time some of the Miami villages were being approached by English traders from the Carolinas, again thanks in part to the early travels of a wandering coureur. Jean Couture also came to the Illinois country with La Salle and Tonti, and also deserted them to make a long trip through the continental interior. He followed the Tennessee River eastward, crossed the Alleghenies, and made his way toward the coast until, in the early I690s, he arrived in Charles Town, South Carolina, where he caused a sensation by telling exaggerated tales of gold deposits and pearl fisheries. These stories, predictably, came to nothing, but in 1700 Couture led a party of South Carolina traders west along the Tennessee and Ohio Rivers to make contact with the French-allied Indians of the Mississippi and western Ohio Valleys. For perhaps a decade Carolina officials and traders sought to make the Tennessee an important trading route, and in $I 70 \mathrm{I}$ I 8 coureurs requested permission to establish a regular trade in furs at Charles Town. In the end the Carolinians failed to make significant inroads in the region, but their efforts were not entirely ephemeral. As late as I7I $_{4}$, a group of Carolina traders had several storehouses on a tributary of the Wabash River, where they traded among the Miami tribes, especially the Ouiatanons and Piankashaws. ${ }^{60}$

The Miamis were not passive observers of these developments. They quickly learned that they could receive European manufactures on better terms from the English than they enjoyed with the French, and they soon acted on their own to take advantage of the fact. When they abandoned the Chicago mission in 1702 in favor of village sites on the Wabash and Miami Rivers, French officials suspected that they wanted

59 Claude de Ramezay to the Minister, I8 Sept. 1714, CSHS-Wisc., vol. XVI, pp. $300-303$.

60 Verner W. Crane, "The Tennessee River as the Road to Carolina: The Beginnings of Exploration and Trade," Mississippi Valley Historical Review, 3 (1916), 5-I4; 
to be closer to their English connections. The resident missionary at Chicago wrote that the Miamis "have never been seen more eager in hunting the beavers than since they received fine belts from the English." During the next several years, the presence of Miami Indians was noted in western Pennsylvania and also at Albany, where they first visited in 1708 . They were so pleased by the terms of trade at Albany that they promised to return again the following year. ${ }^{61}$

Such trans-imperial trading contacts suggest that, from the very earliest years, commerce and empire were uncomfortably matched: an expanding sphere of contacts and trade could as easily undermine as promote stable imperial growth. Administrators in both colonial systems were beginning to learn this lesson in the first several decades of the I 8th century, and no career drives home the point as clearly as that of the uncommon, enigmatic French adventurer Étienne de Véniard de Bourgmont. ${ }^{62}$

Bourgmont began his life as a well-born ne'er-do-well in Normandy, where as a young man he was caught poaching game on monastery lands. He fled to Canada and entered military service rather than pay his fine, and in 1706 he was assigned to the Detroit garrison. Within months he deserted from the service with two fellow soldiers and a woman named Madame Tichenet, who left a husband and several children behind at Detroit; ${ }^{63}$ for more than a decade thereafter Bourgmont's movements cast only an occasional shadow across the documentary record. He and his companions briefly formed an outlaw colony on Lake Erie, but they scattered when one of the deserters was caught,

CSHSWisc., vol. XVI, pp. 208-210; vol. XVII, 475n.

61 Mermet to Cadillac, I9 Apr. 1702, Michigan Pioneer and Historical Society Collections, vol. XXXIII (Lansing, I904), p. I I 8; references to the Miamis in western Pennsylvania appear periodically, but see, e.g., Pa. Col. Recs., vol. II, pp. I 2 I-I 22 (the Miamis are often called Twightwees in the English records of this period); Lord Cornbury to the Board of Trade, 20 Aug. I 708, NYCD, vol. V, p. 65.

62 The best account of Bourgmont's life is Frank Norall, Bourgmont: Explorer of the Missouri, I698-1725 (Lincoln, NE, I988); although I differ from Norall on certain points of emphasis, what follows is based primarily on his account. See also Louise Dechêne's essay in George W. Brown, gen. ed., Dictionary of Canadian Biography (Toronto, 1966- ), vol. II, pp. 645-647, and Milo M. Quaife, "Detroit Biographies: The Sieur de Bourgmont," Burton Historical Collection Leaflet, 6 (1928), 49-63.

63 This was only one episode in the long and storied life of Madame Tichenet. Within a few years she had resurfaced in Albany, where she became known as Madame Montour. She soon married an Oneida chief and began to serve the governor of New York as an interpreter. Eventually she and her husband moved to the vicinity of Shamokin, where their friend and associate Shickellamy was serving as an Iroquois overseer to the Pennsylvania Indians. For decades she and her son, Andrew, were prominent figures in the colony's intercultural relations. 
tried, and sentenced to death. For the next several years Bourgmont was apparently active as a coureur de bois, headquartered perhaps among the Miami tribes but traveling widely along the Ohio, Mississippi, and Missouri Rivers. He soon became one of the first Frenchmen to establish trading connections with the Missouri tribes independently of Illinois middlemen; by I 7 I 4 he had married a daughter of a Missouri chief and they had a newborn son.

Between I 7 I 3 and I7 I 8 Bourgmont was also making contacts in official circles in New Orleans and publicizing his wide-ranging travels and connections. By the end of the decade the governor of Louisiana, Jean-Baptiste Le Moyne de Bienville, decided to employ Bourgmont as an official ambassador to the Missouri tribes; in 1720 he was sent to Paris, knighted, and named commander of a new post to be erected on the Missouri River. From such a base, Bourgmont assured his superiors, he could make "peace among all the Indian tribes between Louisiana and New Mexico in order to open a safe trade route." ${ }^{64}$ In exchange for his service, Bourgmont requested that the king admit him to the ranks of the French nobility. The Duc d'Orleans, acting as regent for Louis XV, accepted his terms and, after a two-year delay, sent him back to Louisiana. A decade and a half after Bourgmont ignominiously deserted his post at Detroit, he had thus parlayed his wide-ranging knowledge of the North American landscape and its inhabitants into a knighthood, the command of a new outpost, and the promise of a noble title.

The Duc d'Orleans and his advisers were pursuing two complementary goals in the Bourgmont mission. On the one hand, if he was successful the French trading sphere in North America would be dramatically expanded; on the other, an alliance with the Padouca tribe in the southwest would provide a valuable buffer between the French outposts on the Mississippi River and the Spanish presence in New Mexico. Armed with a royal commission, Bourgmont finally left New Orleans for the Missouri River early in the spring of 1723 , accompanied by a small (and discontented) group of Frenchmen and his son, now nine years old. During the first winter they built Fort d'Orleans on the north bank of the Missouri, midway between the mouths of the Osage and Kansas Rivers. In the following year, after a long and difficult journey, Bourgmont and his party finally made peace with the Padoucas on behalf of Louisiana and its allies on the Missouri.

Bourgmont still had one task left. His final instruction was to persuade "some of the chiefs of the principal Indian tribes to travel with him to France, in order to give them an idea of the power of the

${ }^{64}$ Quoted in Norall, Bourgmont, p. 34. 
French." ${ }^{65}$ In November 1724 , he set out from the Missouri post with a delegation of chiefs from the Missouri, Osage, and Oto tribes and the daughter of a Missouri chief. On their way through the Illinois country they were joined by a Jesuit superior, Father Nicolas-Ignace Beaubois, and five Illinois chiefs. To reduce expenses, Io of the I 5 Indians were sent home once they reached New Orleans. The other five set sail along with Bourgmont and Beaubois for Paris, where they were fêted by the nobility and caused a great sensation with the public. The climax of the visit came when they were invited to Fontainebleu for an audience with the fifteen-year-old Louis XV. Three days later he invited them to hunt with him in the royal woods, and before they left to return to America he gave each of them tokens by which to remember their visit. ${ }^{66}$

The Indian embassy orchestrated by Bourgmont may have been the social event of the season in Paris, but as a substantive diplomatic mission it accomplished nothing. The Indian tribes contacted by Bourgmont on his long trek into the interior made only a faint and fleeting impression on the minds of his superiors in France; the Padoucas were quickly forgotten altogether, and the Missouri post just as quickly became the exclusive province of coureurs who were criticized for their lawless ways. Nor were the descriptions of Paris offered by the Indian delegates given much weight among their people. In the Illinois country, where Frenchmen were commonly associated with smelly clothes, squalid huts and $\log$ forts, a traveller reported that "[e]verything which Chikagou [Agapit Chicagou, the Michigamea chief who made the trip] has related to his countrymen, with regard to France, has appeared to them incredible. 'They have bribed you,' said some to him, 'to make us believe all these beautiful fictions." Even his relatives and friends, who would not contradict him directly, concluded that the French must have given him some charm that made him imagine carriages that seemed to float above the ground, gardens and fountains of unimaginable ingenuity and beauty, and a capital city that stretched farther than the eye could see. Nothing in their own experience with the French even hinted that they might be capable of realizing the wonders he described. ${ }^{67}$

65 Quoted in Norall, Bourgmont, p. 36.

${ }^{66}$ See Norall, Bourgmont, pp. 81-88; Jacob P. Dunn, ed., "The Mission to the Ouabache," Indiana Historical Society Publications, vol. III (Indianapolis, 1902), pp. 289-293.

67 For a contemporary Parisian account of the visit, see the Mercure de France, Tome IX, Decembre 1725 (repr. Geneva, 1968), 2827-2859; for complaints about the Missouri post, see, e.g., [Anon.], “Memoire concernant les Ilinois," I 732, MG I, série $F^{3}$, vol. 24, partie 3, 603-6I2, NAC [orig. Collection Moreau de Saint-Méry, Archives Nationales des Colonies, Paris]; for traveler, Le Petit to d'Avaugour, I 2 July I730, $J R$, vol. LXVIII, pp. 2I3-2I7. 
But if Bourgmont's efforts in the name of the crown ultimately meant nothing to the empire, they served Bourgmont himself remarkably well. He never returned to America; instead, he married a Frenchwoman and retired to his family estate in Normandy, where they lived comfortably. He was elevated to the nobility and took as his coat of arms "a naked savage reclining on a mountain of silver." ${ }^{68}$ No image could better have captured the spirit of Bourgmont's term of public service, but its meaning is ambiguous: the colonial enterprise, in part through Bourgmont's efforts, was supposed to provide France with a lucrative Indian trade and mountains of silver from phantom mines along the Mississippi and its tributaries. But these were unrealized hopes. Instead, riches and exotic adventure were Bourgmont's personal reward; they were never translated into meaningful gains for the empire.

Just as New France's coureurs became free agents in the continental interior, pursuing their own interests with little regard for the imperatives of empire, Pennsylvania's Ohio Valley traders created a world unto themselves in the west. In so doing, they often flaunted the interests of creditors; ignored the strictures of colonial officials against a variety of offenses, including the liquor trade; and casually risked triggering international conflicts as their commercial activities undermined diplomatic alignments and threatened to remake the map of the Ohio Valley. ${ }^{69}$ Though the characteristics of the traders in the two empires were quite similar, the problems they caused were very different. Throughout the first half of the I 8 th century, New France was plagued by coureurs and Indian allies who carried their trade to British markets, where they could almost always get better terms than they did at French posts. Britain's colonies suffered, in effect, from the opposite problem: as the Pennsylvania trading network stretched farther and farther into the Ohio Valley, the British empire was placed in the uncomfortable position of defending the consequences of their activities. By the early I750s, Pennsylvania had established a tenuous string of Indian alliances connecting it with several groups about whom its officials knew, literally, almost nothing at all. In the end, the threat of British commercial expansion in the Ohio Valley was more than the officials of New France could bear; the opening act of the Seven Years' War was an attempt by the French to reclaim, through intimidation, what they had lost by virtue of a faltering overseas commercial empire.

${ }^{68}$ Norall, Bourgmont, pp. 87-88.

69 For a perceptive study of the importance and effects of the liquor trade see Peter Mancall, Deadly Medicine: Indians and Alcohol in Early America (Ithaca, 1995). 
Among the Britons drawn to the Ohio Valley, none exemplifies the type so clearly as George Croghan, who quickly rose to dominate Pennsylvania's western trade. Croghan came to Pennsylvania from Ireland in I74I. He spoke with a thick brogue, and although he was a tireless writer his orthography and spelling were so bad that he was accounted nearly illiterate by at least one correspondent. He was a flamboyant, hard-drinking man cut to the mold of his occupation, but he was not regarded, like fellow trader Michael Teaffe, as "more bold than prudent." On the contrary, Croghan won allies among Indians and colonists alike (and even, late in his career, in the leading circles of London society) with an unusual combination of shrewd calculation and open-handed affability. When he was among the Indians, a traveling companion found him "most enterprising," but the commentator was also disturbed by Croghan's dissembling manner; he noted that Croghan "can appear highly pleased when most chagrined and show the greatest indifference when most pleased."70

As a businessman Croghan was an energetic self-promoter with little regard for order, careful recordkeeping, or, to hear some of his associates tell it, fair dealing. Croghan was supplied in the Indian trade by at least four Philadelphia dry goods merchants, and he was periodically in debt to each of them; his ventures were heavily capitalized by several other Philadelphians, especially Richard Hockley and Richard Peters; and he formed trading partnerships for specific undertakings with William Trent, Robert Callender, and Michael Teaffe. In turn, he employed, at times, more than a score of men, kept numerous servants and slaves, and on occasion used over a hundred packhorses to carry on his trade. The tangle of obligations and debts created by these arrangements would have been difficult for even the most assiduous bookkeeper to follow; for Croghan, it was utterly impossible. Whether he intentionally slighted the interests of his partners and backers in favor of his own, as his creditors occasionally charged, or he was simply too much the tireless adventurer to spend time poring over his accounts, his business practices failed to keep up with his trading enterprise. Throughout his career as a trader, Indian agent, and land speculator, Croghan was periodically forced to remain in the backcountry for fear that he would be imprisoned for debt if he appeared in Philadelphia. ${ }^{71}$

70 Albert T. Volwiler, George Croghan and the Westward Movement, I74I-I782 (Cleveland, 1926), pp. I7-5 I; George B. Wainwright, George Croghan: Wilderness Diplomat (Chapel Hill, 1959), pp. 3-46, quote: p. I0; George Morgan to his wife, in Clarence Alvord and Clarence Carter, eds., The New Regime, $1765-1767$, Collections of the Illinois State Historical Library, vol. XI (Springfield, I9I6), pp. 3 I6-3 I7.

71 Volwiler, Croghan, pp. 39-4I; Wainwright, Croghan, throughout. 
But if Croghan was a suspect figure in the Pennsylvania capital, he was admired and respected in the West. In the early 1740s he established a trading base among the Shawnees, Delawares, and Mingos on the Allegheny and upper Ohio which was soon unrivaled by any of his competitors. When Logstown, a multiethnic trading village on the upper Ohio, was founded in the mid-I740s, Croghan's position of preeminence was confirmed by the fact that the town's central trading house belonged to him. From his base at Logstown, Croghan quickly began to extend his trading contacts farther downriver. In addition to the Shawnee, Delaware, and Mingo settlements that were beginning to spread out through the valley, Croghan was also drawing French allies into the net of British trade. A Wyandot band from Detroit, under the leadership of a chief named Orontony (known to the British as Nicolas), built a new village for themselves on Sandusky Bay, on the south shore of Lake Erie, to be closer to the Pennsylvania traders. Others remained at Detroit but crossed the lake to trade with Croghan. On occasion, Croghan's men ventured within sight of the French fort at Detroit to trade with the post's ostensible allies. ${ }^{72}$

During the 1740 , France's overseas commercial empire grew steadily weaker; as it did, the Pennsylvania traders gained influence throughout the Ohio Valley. Developments in the Atlantic theater during the War of the Austrian Succession, known in the British colonies as King George's War (I739-I748), seriously disrupted the Indian trade throughout French North America. Between $\mathrm{I} 742$ and $\mathrm{I} 748$ the shipping lines that tied Canadian merchants to their suppliers in Paris were challenged by British seapower, and with the capture of Louisbourg by New England forces in I 745 - "the Gibraltar of the New World," which guarded the Gulf of St. Lawrence - the trickle of merchandise dried up almost entirely for several trading seasons. Canadian merchants effectively lost the capacity, for a time, to carry on the Indian trade in the Ohio Valley at all. In I745 the governor of Canada begged traders to go west as a personal favor to him, and the next year he allowed the monopoly leaseholders at Ouiatanon to remain at the post free of charge, "in order to maintain the savages of the post until times change. ${ }^{73}$ By the late $1740 \mathrm{~S}$

72 Conrad Weiser's Journal, 30 Aug. I748, Weiser Collection, HSP; Croghan to Richard Peters, 26 May I747, Pa. Arch. [Ist Ser.], vol. I, p. 742; Pa. Col. Recs., vol. V, p. 72; Jonquière to Clinton, Io Aug. I75 I, NYCD, vol. VI, pp. 73 I-734; Croghan to William Johnson, I 4 Mar. I757, ibid., vol. VII, p. 267.

${ }^{73}$ Eccles, Canadian Frontier, Pp. I4I-I 53; Fred Anderson, A People's Army: Massachusetts Soldiers and Society in the Seven Years' War (Chapel Hill, 1984), 8; Beauharnois and Hocquart to the Minister of the Marine, 22 Sept. 1746, IndHSProc, vol. XVIII, p. I95; see also Hocquart à Monsieur le controlleur général, I6 Oct. 1744, in H. A. Innis, 
the French trading empire in the Ohio Valley had completely collapsed; in its place, Pennsylvania traders gained new commercial partners along the entire length of the Ohio Valley, including many members of the Illinois and Miami confederacies.

Especially for the three Miami tribes, who had a long acquaintance with British markets, the opportunity to trade with the Pennsylvanians was difficult to resist. By the mid-I740s, the circuit that Croghan and his fellow traders followed took them as far as the Shawnee town at the mouth of the Scioto River. A faction within the Miami tribe soon considered moving to a new site, easily accessible to the Pennsylvania traders from the Shawnee town on the Scioto. In the principal Miami town of Kekionga the preeminent chief of the French alliance, Le Pied Froid, stood firm in his loyalty. But when a rival leader known as La Demoiselle abandoned Kekionga in the spring of 1748 to found the town of Pickawillany on the Great Miami River, 50 or 60 miles to the south, nearly the entire town - about 400 families - followed; only Le Pied Froid's own family remained with him in Kekionga. ${ }^{74}$

The Pennsylvania traders immediately added Pickawillany to their trading circuit. George Croghan, John Frazier, Hugh Crawford, and their associates and employees began to reap astonishing rewards from their new contacts with the Miamis, as the records of Pennsylvania's fur and skin exports for these years illustrate (Fig. 2). In the spring of 1749 two of Frazier's employees had to make two trips to Pickawillany because they received "more Skins than they could carry with their horses at one time." Soon the Miamis at Pickawillany were joined by defectors from the Piankashaw and Ouiatanon tribes as well. By early 1752 , the commanding officer at the Vincennes post, which had been the principal home of the Piankashaws, wrote with alarm that "we have no more Indians at this post" since their removal to Pickawillany. ${ }^{75}$

Out of these lucrative trading connections developed an awkward diplomatic alliance between the Miami tribes and the Pennsylvania government. When the colony organized a large treaty for all its Indian allies at Lancaster, Pennsylvania in $\mathbf{1 7 4 8}$, a party of Miami chiefs ap-

ed., Select Documents in Canadian Economic History, I497-1783 (Toronto, 1929), p. 4 I 4 .

74 W. Vernon Kinietz, The Indians of the Western Great Lakes, I614-1760, Occasional Contributions from the Museum of Anthropology of the University of Michigan, no. Io (Ann Arbor, 1940), pp. 164, I 8 I.

75 See, e.g., Pa. Col. Recs., vol. V, pp. 437-438, 46I-462, 482-483, quote, p. 482; St. Ange to Vaudreuil, 28 Feb. 1752 , in Theodore Pease and Ernestine Jenison, eds., Illinois on the Eve of the Seven Years' War, $1747-1755$, Collections of the Illinois State Historical Library, vol. XXIX (Springfield, r940), p. 485. 
peared along with the expected Iroquois, Shawnee, and Delaware spokesmen. Apparently with no misgivings, the governor accepted the former French allies as a new, westernmost link in the colony's increasingly tenuous "chain of friendship," which now extended more than I000 miles beyond Philadelphia into the continental interior. This addition not only strained any reasonable definition of alliance, but also made the supposed preeminence of the Iroquois even more questionable. Three years later, spokesmen for the Piankashaw and Ouiatanon Indians at Pickawillany approached Croghan to request that they, too, be admitted to the Pennsylvania alliance. Without authorization of any kind, Croghan hastily "drew up an instrument" that confirmed those two tribes, as well, as distant links in the Pennsylvania chain; the governor and council approved the treaty after the fact. ${ }^{76}$

The Illinois Indians also developed new avenues of trade to the east by midcentury. As the Pennsylvania traders transformed the Ohio River into a conduit to British markets, Illinois residents responded. In the summer of $175 \mathrm{I}$, a group of traders joined forces in the Ohio Valley in a venture that illustrates the range of their options. The group included two Frenchmen, Moreau and La Mirande; the latter's wife; Lalande, their partner, who was a métis (born to one French and one Indian parent) from the town of Kaskaskia in the Illinois country; at least one, and perhaps several, Illinois Indians; an unspecified number of slaves; and later two more French traders, named Deguir and Paget. Together they took full advantage of their available markets: after a season of hunting, one party transported the skins and furs they had accumulated - which included more than 600 deerskins - to a British trading post. Another party carried three boatloads of fat, oil, and salt meat to New Orleans, where chronic food shortages would inflate their value. Nor were Moreau and his associates alone in the undefined borderlands between the French and British empires; they encountered, for example, two British traders at the falls of the Ohio in the company of a métis from Kaskaskia, along with several British-allied Indians. Moreau's report worried the French commander in the Illinois country, who wrote to inform Governor Vaudreuil of the group's activities. "It is these gentlemen, trading with the English," he warned, "who little by little are bringing the English into our rivers." 77

In response to the growing perception that British traders had penetrated "far within our territory," in the words of one alarmed observer, French officials took a series of increasingly aggressive actions to intimi-

76 Pa. Col. Recs., vol. V, pp. 307-319, 522-524.

77 Macarty to Vaudreuil, I 8 and 27 Mar. I752, CISHL, vol. XXIX, pp. 515-5I7, $550-551$. 
date their Indian allies and drive away the offending traders. These actions began with the famous expedition of Céloron de Bienville down the Ohio River in 1749. He was sent to observe and report on the state of the region's Indian population, to frighten away the British traders, and to bury a series of lead plates proclaiming French sovereignty - a weak and ineffectual effort to lay claim to the entire valley on behalf of the crown. Céloron and his associates warned colonial officials that British inroads cut very deeply into the region; Pickawillany, in particular, posed a grave threat to the empire. ${ }^{78}$ The next action addressed the problem of Pickawillany directly: a force of about 240 French-allied Chippewas, Ottawas, and Potawatomis from Michilimackinac attacked the village in June 1752. Most of the town's hunters were absent, but the attackers found many women, some British traders, and about 20 older men and boys at home. The raiders cut out the heart of one British trader and took five more prisoner; they also killed five Indians, including La Demoiselle, whom they boiled alive and ate as the Pickawillany residents looked on. The town was temporarily abandoned after the attack; when a party of British traders visited the site a month later, they found it entirely deserted. ${ }^{79}$

By September, though, the Pennsylvania traders and their formerly French-allied trading partners had rejoined forces on the Wabash River, and this time they were well-armed. The traders brought two cannons, many guns, and three hundred horses to the Wabash, where the proBritish factions of the Miami tribes, in concert with members of several other Ohio Valley Indian groups, had constructed two forts for their protection. ${ }^{80}$ Early in the following spring, the Marquis Duquesne, newly appointed governor of New France, dispatched more than a thousand soldiers and habitants from Canada to build a string of forts that would run from Lake Erie to the forks of the Ohio, which were intended to establish unambiguously France's claim to the Ohio Valley. This is the traditional starting point for a narrative account of the Seven Years' War, a beginning that clearly highlights the fundamental interconnections between the trading world of the Ohio Valley and the imperial pretentions of the European powers. But the escalation of conflict in the region also

${ }^{78}$ For Céloron's journal, see C.B. Galbreath, ed., Expedition of Celoron to the Obio Country in 1749 (Columbus, Ohio, 1921); quote: Father Bonnecamps, "Account of the Voyage of Celoron," $J R$, vol. LXIX, p. 185.

${ }^{79} \mathrm{~Pa}$. Col. Recs., vol. V, pp. 599-60I; William Trent's Journal, in Hanna, Wilderness Trail, vol. II, pp. 29I-299. The commanding officer at Detroit believed the number killed in the attack to have been about twenty-six; see Longeuil to Rouillé, I 8 Aug. I752, CISHL, vol. XXIX, pp. 652-653.

${ }^{80}$ Macarty to Vaudreuil, 2 Sept. I752, CISHL, vol. XXIX, p. 668. 
clarifies the extent to which the world of intercultural trade had a logic and a dynamic all its own, which functioned independently of the colonial imperative and consistently defeated the efforts of imperial administrators to control it or direct it into useful channels.

By the eve of the Seven Years' War, the trading culture of the Ohio Valley was, in fact, an interdependent and interpenetrated world. Although it would be easy to conclude that Britain had won control of the region, this was true only in abstract, systemic terms. In fact, as we have seen, it was the interpenetration of the French and British spheres of influence in the region, and the mixed loyalties of Indians, coureurs de bois, and Pennsylvania traders alike, that were its most striking features. Commercial cross-currents ran in every direction, and the Ohio River had become a highway of international trade that united Indians and traders across the ostensible lines of European sovereignty.

Contacts between colonist-traders from both empires and among Indians from a variety of ethnic backgrounds reached a high-water mark in the late imperial period that was, in some ways, reminiscent of the Mississippian era. A new language of commerce, mediated by a developing core of common interests and concerns and marked by a distinctive material culture, had emerged that blunted the sharp edges of distinct ethnic, national, or tribal differences. In part, the landscape itself produced this result: the interlaced river systems of the Ohio Valley once again helped to create networks of linked communities, with blurred lines of cultural difference, out of the island societies left in the wake of the Mississippian collapse and the demographic catastrophe that followed the European discovery of America. 